\title{
Arsenic and Other Geogenic Contaminants in Groundwater - A Global Challenge
}

\author{
Stephan J. Hug ${ }^{\star a}$, Lenny H. E. Winkelab, Andreas Voegelina, Michael Berga, and Annette C. Johnson ${ }^{a}$
}

Sandmeyer Award 2019

\begin{abstract}
Groundwater is a much safer and more dependable source of drinking water than surface water. However, natural (geogenic) hazardous elements can contaminate groundwater and lead to severe health problems in consumers. Arsenic concentrations exceeding the WHO drinking water guideline of $10 \mu \mathrm{g} / \mathrm{L}$ globally affect over 220 million people and can cause arsenicosis (skin lesions and cancers). Fluoride, while preventing caries at low concentrations, has detrimental effects when above the WHO drinking water guideline of $1.5 \mathrm{mg} / \mathrm{L}$ and puts several hundred million people at risk of dental and skeletal fluorosis. In this article, we report on the geochemistry and occurrence of arsenic and fluoride in groundwater and on the development of global and regional risk maps that help alert governments and water providers to take appropriate mitigation measures for the provision of safe drinking water. We then summarize research on the removal of arsenic and fluoride from drinking water, focusing on adapted technologies for water treatment. Finally, we discuss the applicability of various measures in a larger context and future challenges in reaching the goal of access to safe drinking water for all.
\end{abstract}

Keywords: Arsenic · Fluoride · Geogenic contamination · Groundwater

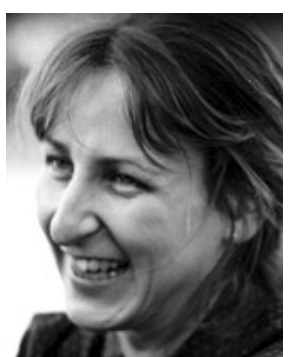

Annette Johnson obtained a $\mathrm{PhD}$ in Applied Geochemistry from Imperial College London in 1984. After postdoctoral studies at Eawag and Oregon State University, she resumed at Eawag in 1991 as group leader pursuing research on inorganic anthropogenic substances. In 2002, she joined the natural geogenic contaminants group conducting research on fluoride removal and risk maps, and initiated and led the international and transdisciplinary project Water Resource Quality. Sadly, Annette Johnson passed away in November 2015 and could not continue her projects in Africa and India. Her contributions and commitment to access to clean water in low-income countries were exemplary.

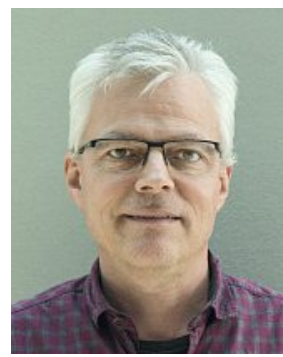

Michael Berg earned a PhD in Environmental Geochemistry at the Karlsruhe Institute of Technology. In 1992 he joined Eawag, where he became group leader in 2002 and head of department in 2014. His research focuses on the occurrence, fate and behavior of organic and inorganic contaminants in groundwater and surface water environments, with a specific interest in biogeochemical processes at local to regional scales. Since 1998, together with the co-authors, he initiated various studies on water quality and mitigation in Asia, where geogenic groundwater contamination is a major concern. Current research includes mechanistic field studies and geospatial prediction modelling of groundwater quality.

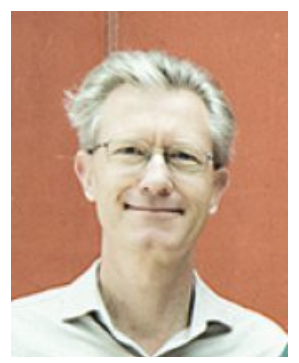

Stephan Hug obtained his $\mathrm{PhD}$ in Physical Chemistry from the University of California at Santa Cruz (1989). After postdoctoral studies at Stanford University, he joined Eawag in 1992. His general areas of research are aqueous geochemistry and the study of mechanisms and kinetics in solution and on surfaces with application of infrared spectroscopy. As a group leader, he started work on arsenic removal in 1999. Together with Michael Berg and Annette Johnson, he initiated various projects addressing geogenic pollution of groundwaters and soils. He continues to work on methods for the removal of arsenic and uranium in Switzerland and other countries.

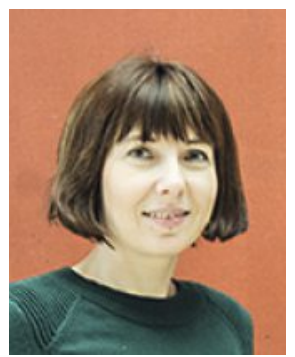

Lenny Winkel obtained her $\mathrm{PhD}$ in Geochemistry at ETH Zurich (2006). She joined the Eawag arsenic research group in 2006 as a postdoc and worked with Michael Berg and Stephan Hug on the development of risk maps for arsenic and other geogenic contaminants. From 2008 to 2011, she was an Experienced Researcher in the EUfunded project AquaTRAIN. In 2011, she was awarded a SNSF professorship and promoted to Associate Professor at ETH Zurich in 2018. Her current research is aimed at understanding the processes controlling the biogeochemical cycling and environmental distribution of trace elements through modelling, field and laboratory studies. 


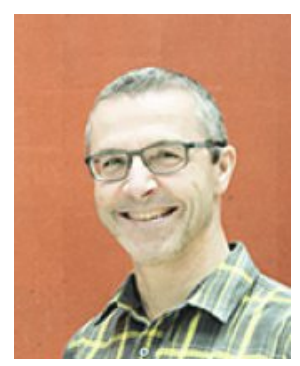

Andreas Voegelin obtained his $\mathrm{PhD}$ in Natural Sciences at ETH Zurich (2001). He worked as a scientist in the Soil Chemistry Group at ETH Zurich from 2002 to 2008. He then joined Eawag in 2009 as leader of the group Molecular Environmental Geochemistry. His research focuses on mechanistic and quantitative aspects of solid-solution interface reactions of trace elements and on the speciation and fate of trace elements in natural and engineered systems. Current research projects address the sorption and solubility of thallium in soils and sediments or the formation and transformation of $\mathrm{Fe}$ oxides and consequences for trace element and phosphorus dynamics.

\section{Introduction}

In 2020, a century after the treatment and disinfection of drinking water became the norm in industrialized countries, two billion people out of a global population of 7.8 billion still have no or only limited access to safe drinking water. Universal and equitable access to safe and affordable drinking water by 2030 is a target of the United Nations Organization under its Sustainable Development Goal 6, "Ensure availability and sustainable management of water and sanitation for all."'[1]

Groundwater is the largest source of liquid freshwater on Earth (69\% of fresh water is in icecaps, $30 \%$ in groundwater, and $1 \%$ in surface waters). ${ }^{[2]}$ With increasing population densities and pollution of surface waters, groundwater has become the major source of drinking water in most countries. Groundwater usually provides a more steady supply of drinking water than seasonably variable lakes, rivers and ponds and is increasingly also used for irrigation. However, large-scale groundwater abstraction in the last decades is threatening groundwater resources around the world, and may lead to groundwater scarcity and water quality

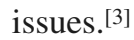

Due to natural barriers between surface and groundwater and the natural filtering properties of fine-grained sediments in aquifers, groundwater usually has much lower concentrations of pathogens than surface water. Due to the intense interaction between groundwater and aquifer materials, the chemical quality of groundwater is determined by the solubility of minerals and chemical reactions that control the release of main and trace elements from aquifer materials. The main elements calcium (Ca), magnesium $(\mathrm{Mg})$, sodium $(\mathrm{Na})$ and potassium $(\mathrm{K})$ occur in groundwater in a wide range of concentrations, from a few to several hundred $\mathrm{mg} / \mathrm{L}$, and are beneficial to health and enhance the taste of drinking water. Conversely, geogenic contaminants are unwanted and potentially toxic elements that are naturally present in aquifer materials and are released to groundwater under certain conditions. The most widespread and toxic geogenic contaminants are arsenic (As), mainly in the form of arsenite and/ or arsenate and fluorine $(\mathrm{F})$ in the form of fluoride, both affecting hundreds of millions of people worldwide. Additional widespread geogenic groundwater contaminants are manganese (Mn), uranium $(\mathrm{U})$, radium $(\mathrm{Ra})$, and to a lesser extent, selenium $(\mathrm{Se})$ and thallium (Tl). Dissolved Fe(II) is unwanted because of water taste and aesthetics, but is easily removed by aeration and is not toxic. Manganese and selenium are essential elements at low concentrations but can be toxic at higher concentrations. Another widespread problem is high salinity that can render otherwise acceptable drinking water unsuitable.

Arsenic concentrations in groundwater resources frequently exceed $10 \mu \mathrm{g} / \mathrm{L}$, the drinking water limit set by the World Health Organization (WHO), the EU, US, Switzerland and most other countries. Concentrations of geogenic As in groundwater that are 10-100 fold higher lead to chronic As poisoning and can- cers affecting millions of people. Worldwide, more than 220 million people consume groundwater with As concentrations above $10 \mu \mathrm{g} / \mathrm{L} .{ }^{[4]}$ In many affected regions, As concentrations reach hundreds of $100 \mu \mathrm{g} / \mathrm{L}$. Fluoride in excess of the international limit of $1.5 \mathrm{mg} / \mathrm{L}$ can cause tooth decay and skeletal fluorosis. It was estimated that over 260 million ${ }^{[5]}$ people are affected by groundwater used for consumption with fluoride above $1.5 \mathrm{mg} / \mathrm{L}, 120$ million in India alone, with concentrations frequently from 5-20 mg/L. ${ }^{[6]}$ Other geogenic contaminants, such as U, Ra, Tl, and excess Mn, have various detrimental health effects and affect an unknown number of people worldwide.

Over the last two decades, researchers at the Swiss Federal Institute of Aquatic Science and Technology (Eawag) have studied the geochemistry and occurrence of inorganic and organic compounds in sediments, soils and water, including ground, surface, drinking, waste and atmospheric water. Research at Eawag addresses both natural environments (groundwater, lakes, rivers) and technical systems (drinking- and wastewater treatment facilities). With the discovery of widespread As contamination of groundwaters in West Bengal and Bangladesh in the early 1990s, Eawag scientists started research on As removal from drinking water in Bangladesh and on the assessment of As contamination in Vietnam in 1998. Research on fluoride removal and the development of global scale risk maps started in 2002.

Although the authors of this article have actively studied several chemicals of geogenic origin that are frequent contaminants of groundwater (As, F, Mn, U, Cr, Se, or Tl), this paper focuses on As, and to a lesser extent, on F, because these two geogenic groundwater contaminants affect the largest number of people globally. This paper does not intend to review all research on geogenic contamination of groundwaters, but summarizes our Sandmeyer Award 2019 lectures and, therefore, primarily focuses on our own studies. We emphasize that this work is only a small fraction of contributions by the international research community in a large effort to understand and mitigate geogenic groundwater contamination. The work described in this article would not have been possible without the previous and concurrent work of numerous researchers worldwide and without collaborations and interactions with many colleagues.

\section{Arsenic: Geochemistry, Distribution in Water and Soils, and Mitigation}

\subsection{Arsenic in Groundwater}

Arsenic, an infamous poison for centuries, was discovered as a widespread natural (geogenic) contaminant in groundwater in Taiwan and Chile in 1960-1970. In the early 1990s, when groundwater was already widely used as drinking water in the Bengal Basin, the widespread As contamination of the groundwaters was first discovered in neighboring West Bengal (India) and shortly thereafter in Bangladesh. The switch from surface water to groundwater from 1970-1990 in Bangladesh is an example of both the benefits of groundwater as a drinking water resource and the dangers of using groundwater without proper monitoring. It resulted in a strong reduction of diarrheal disease outbreaks and the death of millions before 1970, but also in the unintended exposure of Bangladesh's rural population to As.

After the discovery of As in groundwaters of West Bengal and Bangladesh, researchers of the University College of London ${ }^{[7]}$ and other groups studied the source and the extent of the As contamination in groundwater in Bangladesh. The British Geological Survey (BGS) conducted and published an extensive survey. ${ }^{[8]}$ It was found that 30-50 million people in Bangladesh were affected by what was described in the WHO Bulletin as the "largest poisoning of a population in history." [9] The toxicity of As and the development of limits for As in drinking water have been reviewed, among others, by Flora ${ }^{[10]}$ and by Schmidt. ${ }^{[1]}$ 


\subsection{Geochemistry, Sources, and Distribution of Arsenic in River Deltas}

The primary sources of geogenic As are minerals of various classes, but it is thought that As sulfides (As-rich pyrite $\left(\mathrm{FeS}_{2}\right)$, arsenopyrite $(\mathrm{FeAsS})$, orpiment $\left(\mathrm{As}_{2} \mathrm{~S}_{3}\right)$, and realgar $(\mathrm{AsS})$ ) are main primary sources of As, in addition to other complex sulfides, containing not only As (and Fe) but also transition metals such as $\mathrm{Co}, \mathrm{Ni}$, and $\mathrm{Cu} .{ }^{[12]}$ These sulfide minerals occur primarily in hydrothermal and magmatic ore deposits. When primary minerals are eroded and weathered under oxic conditions, As is oxidized to arsenite (As(III)) and finally to arsenate (As(v)), and is transported through rivers to sedimentary basins. Fig. 1 illustrates the pathway of As from primary rock minerals to aquifer sediments, with information on As speciation along a profile, for example, from the Himalayan mountain range to the low-lying plains of the Bengal Delta. to As mobilization, and is more important under oxic conditions, is due to the development of high $\mathrm{pH}(>8.5)$ conditions in semiarid or arid environments caused by mineral weathering and high evaporation rates. The high $\mathrm{pH}$ leads to the desorption of As(v) species and other anion-forming elements from mineral oxides. ${ }^{[14]}$ This second mechanism is referred to as high-pH environments later on in the text. However, most of the research described here is related to As(III) release via reductive dissolution of $\mathrm{Fe}(\mathrm{III})(\mathrm{hydr})$ oxides (low-Eh environments). Previous studies have found that elevated As levels in many areas in SE Asia are present in sedimentary deposits from the Holocene epoch (last 10'000 years), which are characterized by relatively high contents of NOM and fresh mineral phases with high sorption capacities for As (mainly as $\mathrm{As}(\mathrm{v}))$. Older aquifers from the Pleistocene epoch (1.8 million - 10'000 years ago), are generally low in As, as these aquifers are characterized by less reducing conditions and weathered sedi-

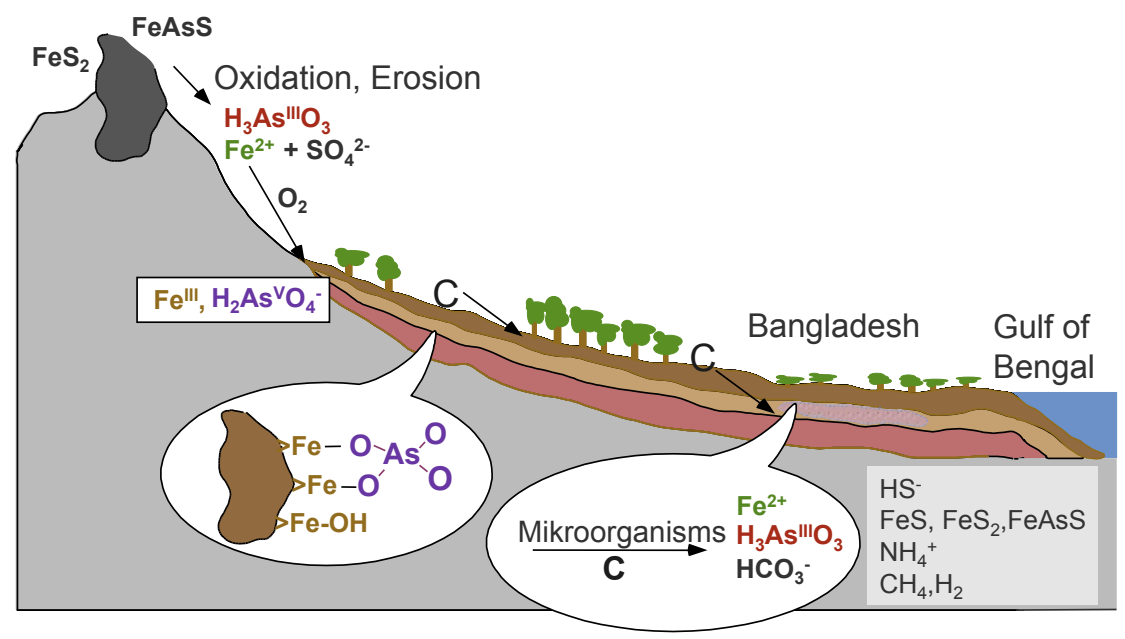

Fig. 1. Simplified illustration of origin, transport and speciation of arsenic in groundwater of sedimentary basins such as the Bengal Delta.

Due to the high charge and small radius of $\mathrm{As}^{3+}$ and $\mathrm{As}^{5+}, \mathrm{As}(\mathrm{III})$ and $\mathrm{As}(\mathrm{v})$ in solution occur mainly as oxyanions. In groundwater, As is mainly present in inorganic forms, i.e. As(III), referred to as arsenite, occurring as $\mathrm{H}_{3} \mathrm{AsO}_{3}$ or $\mathrm{H}_{2} \mathrm{AsO}_{3}^{-}$, depending on the $\mathrm{pH}$, and $\mathrm{As}(\mathrm{v})$, referred to as arsenate, occurring as $\mathrm{H}_{3} \mathrm{AsO}_{4}, \mathrm{H}_{2} \mathrm{AsO}_{4}^{-}$, $\mathrm{HAsO}_{4}^{2-}$ or $\mathrm{AsO}_{4}^{3-}$, from acidic to alkaline conditions. The Pourbaix diagram (Eh-pH diagram) in Fig. 2 shows that at common environmental pH values ( $\mathrm{pH}$ 5-8), As(III) mainly occurs as uncharged $\mathrm{H}_{3} \mathrm{AsO}_{3}$ and $\mathrm{As}(\mathrm{v})$ as negatively charged $\mathrm{H}_{2} \mathrm{AsO}_{4}^{-}$and $\mathrm{HAsO}_{4}{ }^{2-}$. Therefore, $\mathrm{As}$ (III) has relatively weak interactions with $\mathrm{Fe}(\mathrm{III})$ hydroxides, oxyhydroxides and oxides, from here on referred to as Fe(III)(hydr)oxides, explaining its solubility and mobility in groundwater. In contrast, anionic $\mathrm{As}(\mathrm{v})$ strongly sorbs to Fe(III)(hydr)oxides and other mineral surfaces and, therefore, strongly partitions to the solid phase (e.g. in aquifer sediments and in Fe-based filter materials).

In the flatter and low-lying part of the Bengal delta, groundwater flow is sluggish, and natural organic matter (NOM) in relatively young aquifer sediments is abundantly available. These widespread environmental characteristics lead to chemically reducing conditions, under which microbially-driven reduction of strongly sorbing $\mathrm{As}(\mathrm{V})$ to poorly sorbing $\mathrm{As}$ (III) and reduction of Fe(III) to $\mathrm{Fe}(\mathrm{II})$ are coupled to the oxidation of NOM in the aquifer. The reduction of $\mathrm{Fe}(\mathrm{III})$ (hydr)oxides, the main sorbents for As, leads to the release of $\mathrm{Fe}^{2+}$ into groundwater and the dissolution of the main substrate for As(v) adsorption. The reduction of $\mathrm{As}(\mathrm{V})$ and $\mathrm{Fe}(\mathrm{III})$ thus trigger the release of As(III), the most mobile and toxic form of As, into groundwater. As the mobilization of As from the sedimentary phase into the groundwater involves both reduction and dissolution of the main host minerals $\mathrm{Fe}(\mathrm{III})$, this process is referred to as reductive mobilization. A second process that leads ments where sorbed As has already been flushed out. ${ }^{[15,16]}$ If sulfate $\left(\mathrm{SO}_{4}^{2-}\right)$ is present in highly reducing aquifers, sulfate reduction can lead to the formation of insoluble As-sulfides, and As(III) is removed from the aqueous phase. Thus, in reducing groundwaters with high sulfate concentrations, dissolved As concentrations are usually low.[17]

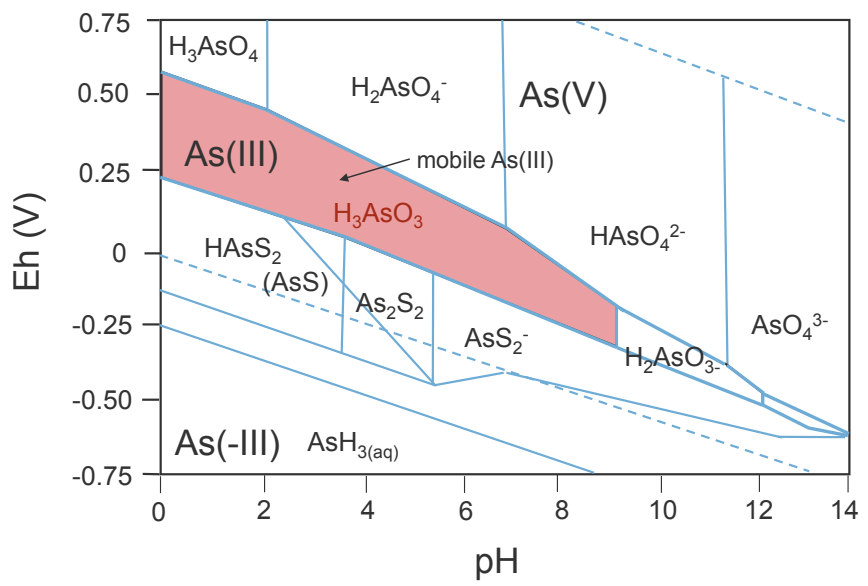

Fig. 2. Speciation and redox chemistry of As. Under oxic conditions, As occurs as As(v) oxyanions, which are negatively charged and strongly adsorb to mineral surfaces. Under anoxic and reducing conditions in the $\mathrm{pH}$ range $5-8$, As is present as $\mathrm{As}(\mathrm{III})$ in the form of uncharged $\mathrm{H}_{3} \mathrm{AsO}_{3}$ (red marked area), which adsorbs only weakly and is thus mobile in aquifers. Under strongly reducing conditions in the presence of reduced sulfur (sulfide), As is sequestered into sparsely soluble As (and Fe) sulfides. Diagram for $25^{\circ} \mathrm{C}, 1$ atmosphere, $10 \mu \mathrm{M}$ As and $1 \mathrm{mM}$ total sulfur (S), redrawn and adapted from Ferguson and Gavis, 1972. ${ }^{[13]}$ 


\subsection{Arsenic Concentrations in Groundwater on Regional Scales}

To obtain an overview of the distribution of As concentrations in groundwater in a specific region, groundwater quality surveys have proven to be essential. The first broad-scale survey was conducted in Bangladesh by BGS/DPHE in 1998-2001 (see Fig. 3). ${ }^{[8]}$ Typically, in these surveys, groundwater samples are collected at a predefined spatial scheme (e.g., in Fig. 3, 1 sample per $37 \mathrm{~km}^{2}$ ) and subsequently analyzed in the laboratory by spectrometric or spectroscopic methods or directly in the field with test kits. As illustrated in Fig. 3, the concentrations of As in tubewells are generally higher in southern regions of Bangladesh, however, looking at a smaller scale, it becomes evident that As levels can be highly heterogeneous on a regional level and even within villages. This heterogeneity could be explained by different wells tapping different aquifers at different depths, but also by other variables with small-scale variation such as hydrology, redox conditions, and differences in sediment and/or NOM composition.

Shortly after the initial reports of the As crisis in Bangladesh were published, Berg et al., ${ }^{[18]}$ in a Swiss-Vietnamese collaboration, conducted a groundwater quality survey in Hanoi and the Red River (RR) delta in Vietnam (Fig. 4). The survey was inspired by the geological similarities between the Bengal and RR Deltas and indeed, widespread arsenic contamination was found in the RR Delta and later also in the Mekong Delta in Vietnam and Cambodia, which also proved to be a hotspot of As as well as of Mn. ${ }^{[15,17,19]}$
Fig. 3. Arsenic concentrations in shallow tubewells (mostly 25-40 $\mathrm{m}$ deep) in Bangladesh are variable on large and small scales. Particularly high As concentrations are frequently found in the south and southeast of the country. On a village scale, low concentrations can occur in the close vicinity of high concentrations, although with lower probability in heavily affected areas. Figures from BGS and DPHE, 2001. ${ }^{[8]}$
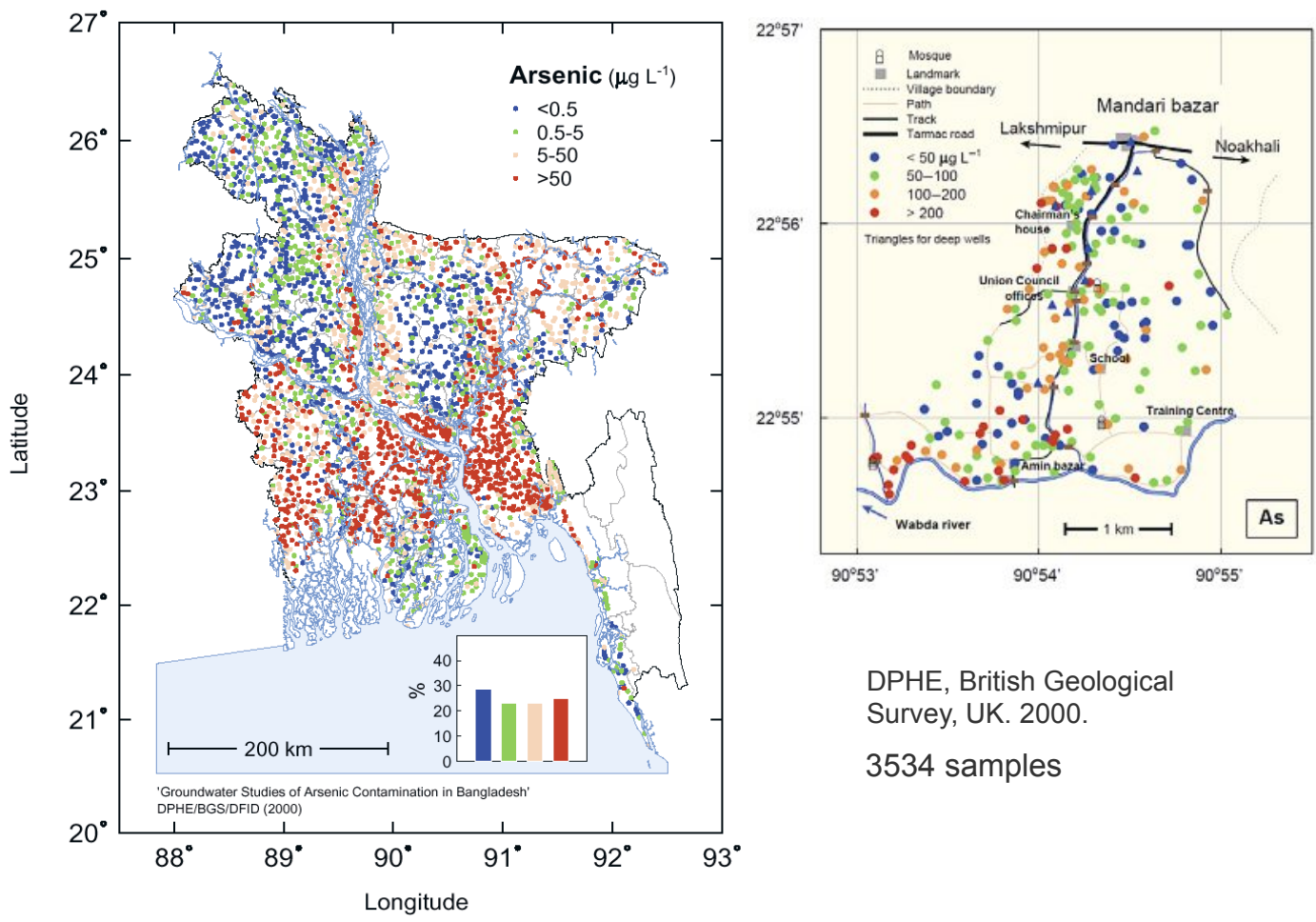

DPHE, British Geological Survey, UK. 2000.

3534 samples
Fig. 4. As concentrations in groundwater of the RR Delta. The majority $(72 \%)$ of the wells exceed the WHO guideline of $10 \mu \mathrm{g} / \mathrm{L}$, with the southern region being most severely affected with levels $>300 \mu \mathrm{g} / \mathrm{L}$.

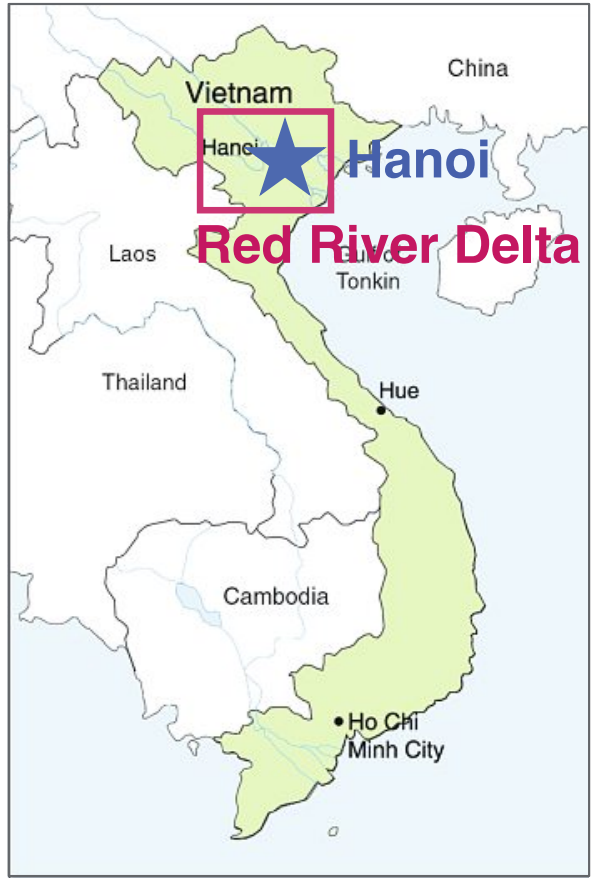

Hanoi 4 Mio.

Red River Delta 11 Mio. 


\subsection{Geochemical Modeling and Risk Maps}

Although known for almost two decades, the investigation of groundwater geogenic contamination has been fragmented, relying on research initiatives scattered around the world. However, a deeper geochemical understanding of the process and the availability of groundwater data from regional/country-wide surveys enabled the geostatistical modeling and construction of predictive maps that pinpoint the risk of geogenic As contamination. These risk maps, indicating probabilities of As concentrations exceeding $10 \mu \mathrm{g} / \mathrm{L}$, have since been adopted by water and health authorities to raise awareness of contaminated groundwater, particularly where groundwater quality has never been assessed (e.g., in Sumatra, ${ }^{[16,20]}$ Cambodia, ${ }^{[21]}$ and South Louisiana ${ }^{[22]}$ ).

Creating these probability maps was enabled by the development of novel geostatistical modeling procedures using logistic regression, thereby combining expert geochemical knowledge with water quality measurements and relevant geospatial parameters. ${ }^{[23-25]}$ This procedure is different from other approaches where interpolation (e.g., kriging) is used without accounting for geochemical processes. ${ }^{\text {[21,26] }}$

The geospatial data in this modeling approach is used as proxies that represent the natural causes of elevated As or F concentrations in groundwater. For example, Holocene geology and aquifers enriched in NOM are reflected by proxies like sedimentary depositional environments, soil properties and topography (Fig. 5).

Fig. 6 shows probability maps that were developed at regional to global scales. In 2008, Amini et al. ${ }^{[24]}$ created the first global predictive maps for As, differentiating between low-Eh and highpH environments (Fig. 6a), using some 20,000 points of measured groundwater As concentrations from mainly South and Southeast (SE) Asia, Europe, and the US. Further development of this approach was successfully applied to the sub-continental scales of SE Asia ${ }^{[20]}$ (Fig. 6b) and China, ${ }^{[27]}$ whereby only a few surface parameters were needed to produce statistically significant risk maps of arsenic reaching concentrations above $10 \mu \mathrm{g} / \mathrm{L}$. In SE Asia, six parameters related to geology and soil proved statistically relevant for the model.[20] The key proxies for As release under reducing conditions were topography (small slopes), geology (sedimentary depositional environment with young, organic-rich sediments), and soil texture (related to drainage). Newly predicted regions in SE-Asia where As had never been tested before were later confirmed by Winkel et al. in Sumatra ${ }^{[16,20]}$ and by van Geen et al. in Myanmar. ${ }^{[28]}$ In China, the topographic wetness index and salinity of the soil were additionally important model parameters. Geospatial information of higher resolution and geological information that differentiates between Holocene and Pleistocene sediments considerably improved the models. Hence, where spatial information on geology at depth is available, the probability of As contamination can even be modeled in three dimensions. This so-called '3D modeling approach' was successfully established for the RR delta in Vietnam (Fig. 6c). In addition to indicating the probability of As concentrations at different aquifer depths, the 3D model for the RR delta identified a massive draw-down of arsenic-rich waters from the Holocene aquifer into deeper (Pleistocene) aquifers that were previously low in arsenic.[29] This finding triggered further research on As contamination of Pleistocene aquifers. ${ }^{[30,31]}$ Furthermore, mechanisms of As contamination were also studied in the Pannonian basin in Hungary and Romania, ${ }^{[32]}$ in Pakistan, ${ }^{[33]}$ India, ${ }^{[6]}$ Burkina Faso ${ }^{[34]}$ and the Amazon Basin. ${ }^{[35]}$

\subsection{Irrigation with As-containing Ground Water and Transfer of As to Soils and Rice}

Bangladesh and other SE-Asian countries largely rely on domestic rice production to feed their populations. Over the last half century, rice production in Bangladesh shifted from rain-fed wet-season rice to high-yielding dry-season rice varieties whose production depends on irrigation with groundwater. Through the large-scale pumping of shallow and often As-rich groundwater into paddy fields, As can accumulate in paddy soils and be transferred into the food chain. The intake of As via rice and other crops therefore represents another threat to people's health. In 2007 , around $38 \%$ of the area of Bangladesh $(70 \%$ of the area used for food production) was irrigated with groundwater, transferring an estimated 1360 tons of As to paddy fields in Bangladesh each year. In a collaboration with ETH Zurich from 2007 to 2010, we studied the extent to which irrigation leads to the accumulation of As in soil and As transfer into rice at a field site $35 \mathrm{~km}$ south of Dhaka, where fields at this time were already being irrigated for about 15 years with water containing $400 \mu \mathrm{g} / \mathrm{L}$ As. Our field data confirmed the hypothesis, that As inputs into paddy fields are spatially heterogeneous and decrease with increasing distance

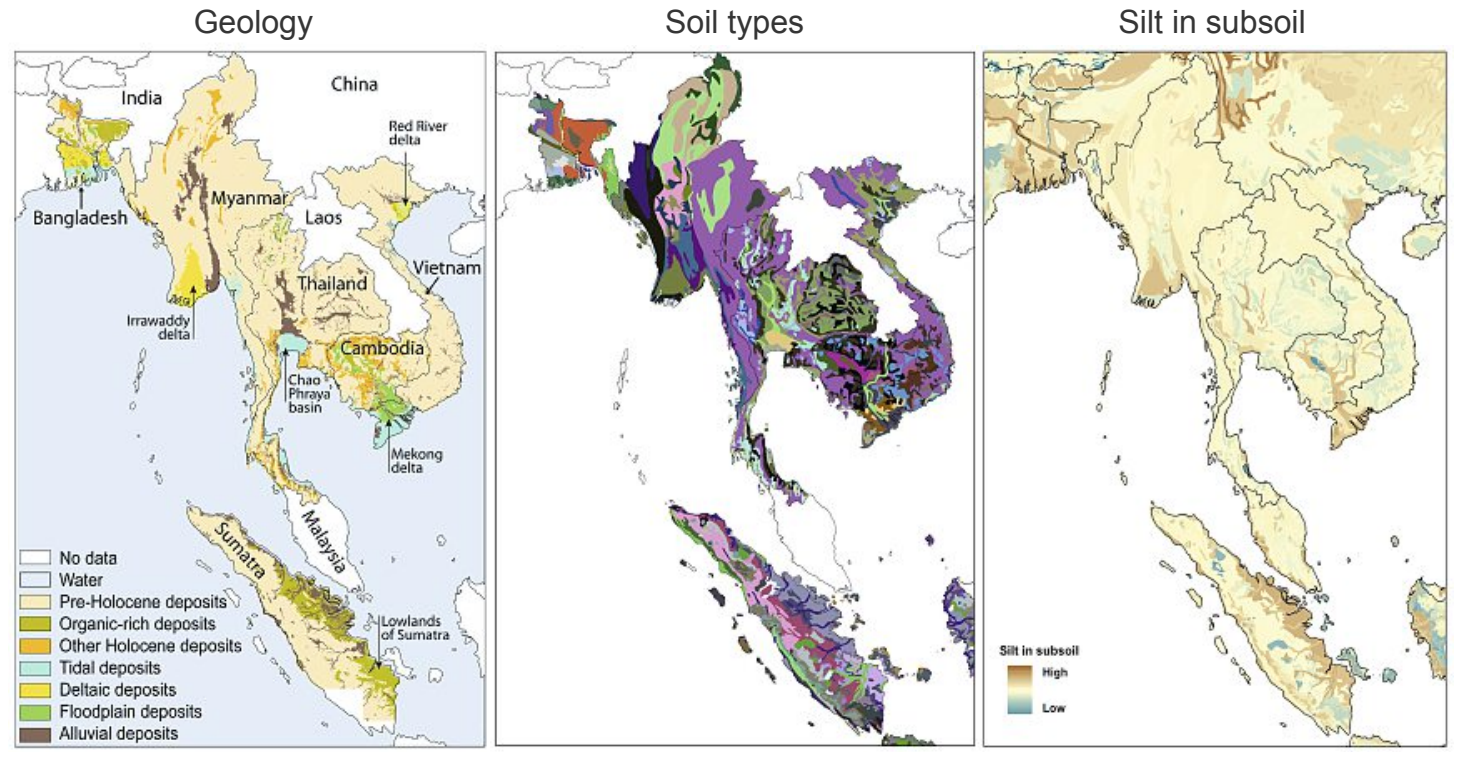

Combination of variables

Fig. 5. Construction of risk maps based on information in available geographic information systems (GIS) on geology, soils types, subsoils, climate (precipitation, temperature, humidity) and knowledge of the geochemical reactions that lead to As release (also see Fig. 15). The most important factors are reducing aquifers, organic-rich sediments, young (Holocene) sediments and low -lying areas (young river deltas). Statistical relationships between variables are determined with logistic regression and calibration with measured As concentrations. Figures partly based on Winkel et al.[20] 
a)

b)

South East Asia

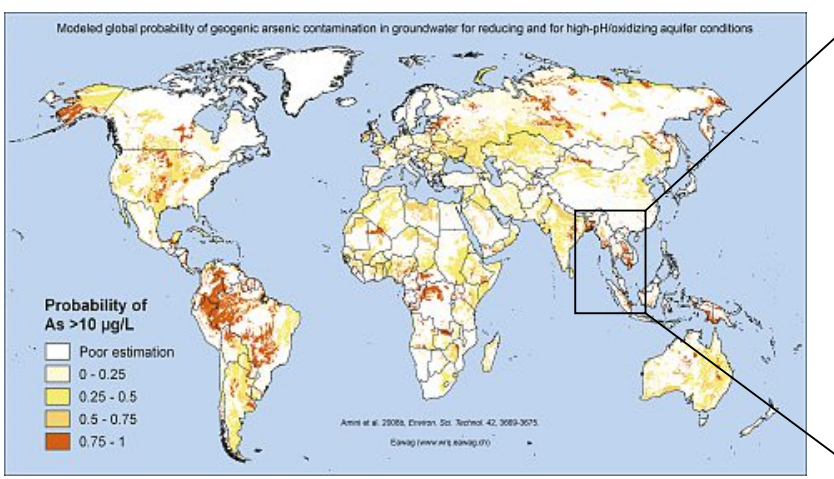

Global

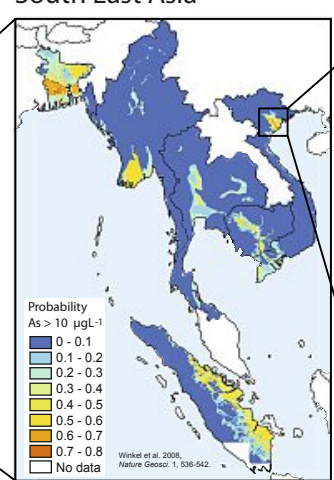

Regional
C)

Red River delta, Vietnam

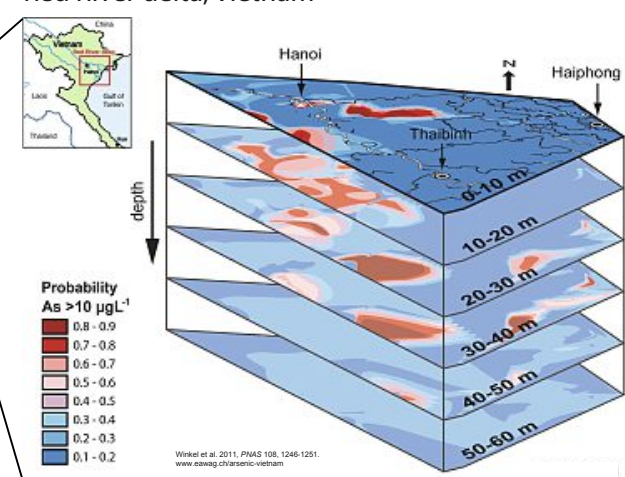

River basin in 3D

Fig. 6. Probability maps of As concentrations exceeding $10 \mu \mathrm{g} / \mathrm{L}$ in groundwater on global to regional scales. a) Global predictions for both reducing and non-reducing/high-pH aquifer conditions, ${ }^{[24]}$ b) SE Asia and Bangladesh, ${ }^{[20]}$ and c) risk of As pollution modelled in three dimensions for the entire RR Delta (Vietnam), illustrated at $10 \mathrm{~m}$ depth intervals. ${ }^{[29]}$ The guideline concentration of the World Health Organisation (WHO) for arsenic in drinking water is $10 \mu \mathrm{g} / \mathrm{L}$.

from the irrigation water source, due to precipitation of $\mathrm{Fe}(\mathrm{III})$ (hydr)oxides with sorbed As along flow paths. ${ }^{[36]}$ Furthermore, we were able to show that irrigation leads to a marked increase in paddy soil As contents, ${ }^{[37]}$ which is partly attenuated by As leaching into deeper soil layers during irrigation or by As release into overlying floodwater during the monsoon season. ${ }^{[38]}$ Based on these results, As levels could be projected to increase further until an equilibrium between irrigation input and leaching losses is reached. ${ }^{[37 b]}$ Research on As uptake by rice further showed that current and projected future soil As contents lead to As contents in rice that pose a threat to human health, and may partly offset the reduction of As exposure achieved by treatment of drinking water. ${ }^{[37 b]}$ Furthermore, rising As contents in paddy soils can lead to significantly lower rice yields, with an estimated loss of 1.4-4.9 million tons annually (7-26\% of the boro harvest), ${ }^{[39]}$ thereby representing a serious threat to food security.

\subsection{Arsenic Removal from Drinking Water}

\subsubsection{Overview of As-removal Methods}

A range of As-removal methods has been developed and applied previously, i.e. in Taiwan during the 1950s and in Chile during the 1970s. To meet the former limit for As of $50 \mu \mathrm{g} / \mathrm{L}$ and the new limit of currently $10 \mu \mathrm{g} / \mathrm{L}$, As-removal methods are applied on all continents. Experiences with As-removal technologies and practical constraints are described and reviewed in Hering et al. in 2017. ${ }^{[40]}$ Common to all currently applied methods is the oxidation of As(III) to the more strongly binding pentavalent As(v) and the sorption or co-precipitation of $\mathrm{As}(\mathrm{V})$ with $\mathrm{Fe}(\mathrm{III})$ (hydr) oxides. Less commonly applied are aluminum salts and $\mathrm{Al}$ (hydr) oxides. Fe(III)(hydr)oxides are preferred because i) they adsorb $\mathrm{As}(\mathrm{v})$ over a larger $\mathrm{pH}$ range, ii) dissolved or colloidal residual $\mathrm{Fe}$ is easily seen as a brown coloration of the water, and iii) $\mathrm{Fe}$ is not connected to possible health concerns as is the case for Al. $\mathrm{Fe}(\mathrm{III})$ (hydr)oxides are pre-fabricated and used in granular form in filters, produced in situ by the addition and hydrolysis of Fe(III) salts, or by the addition of Fe(II) salts with subsequent oxidation with air to $\mathrm{Fe}(\mathrm{III})$. The procedures are shown schematically in Fig. 7.

There are many variations of the basic removal steps. Some water treatment plants use biological oxidation of As(III) and Mn(II) in a sand column (instead of chemical oxidation), followed by precipitation of $\mathrm{As}(\mathrm{V})$ by the addition of $\mathrm{FeCl}_{3} \cdot{ }^{[41]}$ Very large treatment plants usually use the more cost-effective method of precipitation, while medium to smaller plants prefer fixed bed columns. ${ }^{[40}$
Fig. 7. Arsenic removal methods. In reducing waters (on the left of the figure), the first step is aeration to oxidize dissolved Fe(II), bisulfide and other easily oxidizable compounds. As(III) and Mn(II) are oxidized in a second step by addition of chemical oxidants. As(v) is subsequently removed by precipitation with Fe oxides formed by addition of $\mathrm{Fe}$ (II) or Fe(III) salts. Remaining suspended precipitates are removed by sand filtration. An alternative to precipitation (on the right) is removal of As(v) by filtration through a fixed bed column with prefabricated granular Fe(III) (hydr)oxides.
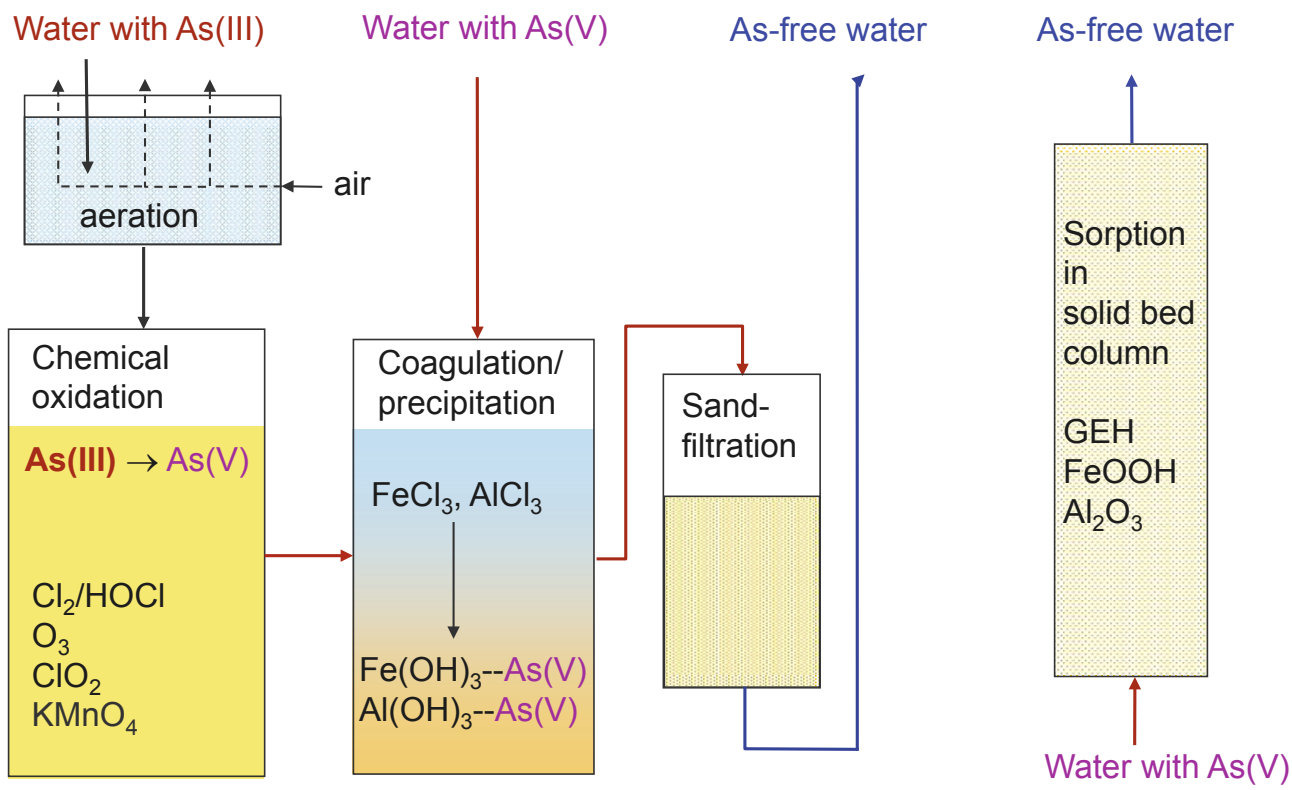


\subsubsection{As-removal with Adapted and Low-cost Technologies}

Eawag researchers started working on As removal in Bangladesh and Vietnam, immediately after the discovery of widescale As contamination in these countries. ${ }^{[18]}$ The challenge in Bangladesh and Vietnam was to achieve As removal with inexpensive methods and locally available materials. Sand filters have been used in Vietnam traditionally to remove the often very high concentrations of $\mathrm{Fe}$ (II) from groundwater. The team of Michael Berg and Vietnamese researchers showed that household and community scale sand filters used to remove Fe(II) can be optimized to also effectively remove As. ${ }^{[42]}$ Arsenic removal with naturally present $\mathrm{Fe}$ is also used in large water treatment facilities in Hanoi. ${ }^{[40]}$ The mechanisms for As removal in sand filters are described in Fig. 8.
In an attempt to achieve acceptable As removal without the need for chemicals and complex procedures, we studied various options. Based on the successful solar water disinfection by exposure of water in clear PET-bottles to sunlight and previous studies on photochemical production of oxidants from $\mathrm{Fe}(\mathrm{III})$-organic complexes, we developed a simple method with photochemically induced oxidation of As(III) to As(V) and concurrent adsorption of $\mathrm{As}(\mathrm{V})$ on precipitated Fe(III)(hydr)oxides. Addition of citrate (in the form of a few drops of lemon juice added per liter of water) leads to formation of $\mathrm{Fe}(\mathrm{III})$ citrate complexes. These complexes are photolyzed with high quantum yields and lead to increased formation of $\mathrm{Fe}$ (II) and $\mathrm{H}_{2} \mathrm{O}_{2}$ and finally $\mathrm{OH}$-radicals or $\mathrm{Fe}(\mathrm{IV})$ in the subsequent Fenton reaction. ${ }^{[45]}$ Although the method works well in water with more than $8 \mathrm{mg} / \mathrm{L} \mathrm{Fe}(\mathrm{II})$, it could not be broadly recommended in

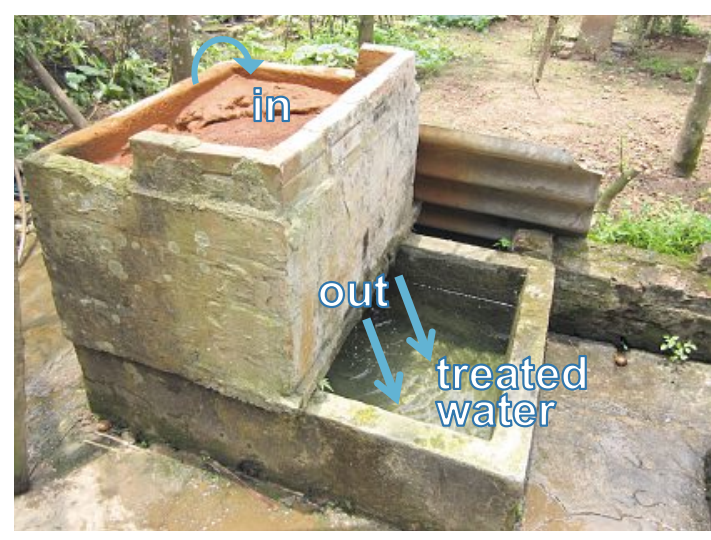

Processes in sand filter

Oxidation of $\mathrm{Fe}(\mathrm{II})$

$\mathrm{Fe}(\mathrm{III})$ precipitation on sand

As(III) oxidation

Adsorption of $\mathrm{As}(\mathrm{III})$ and $\mathrm{As}(\mathrm{V})$

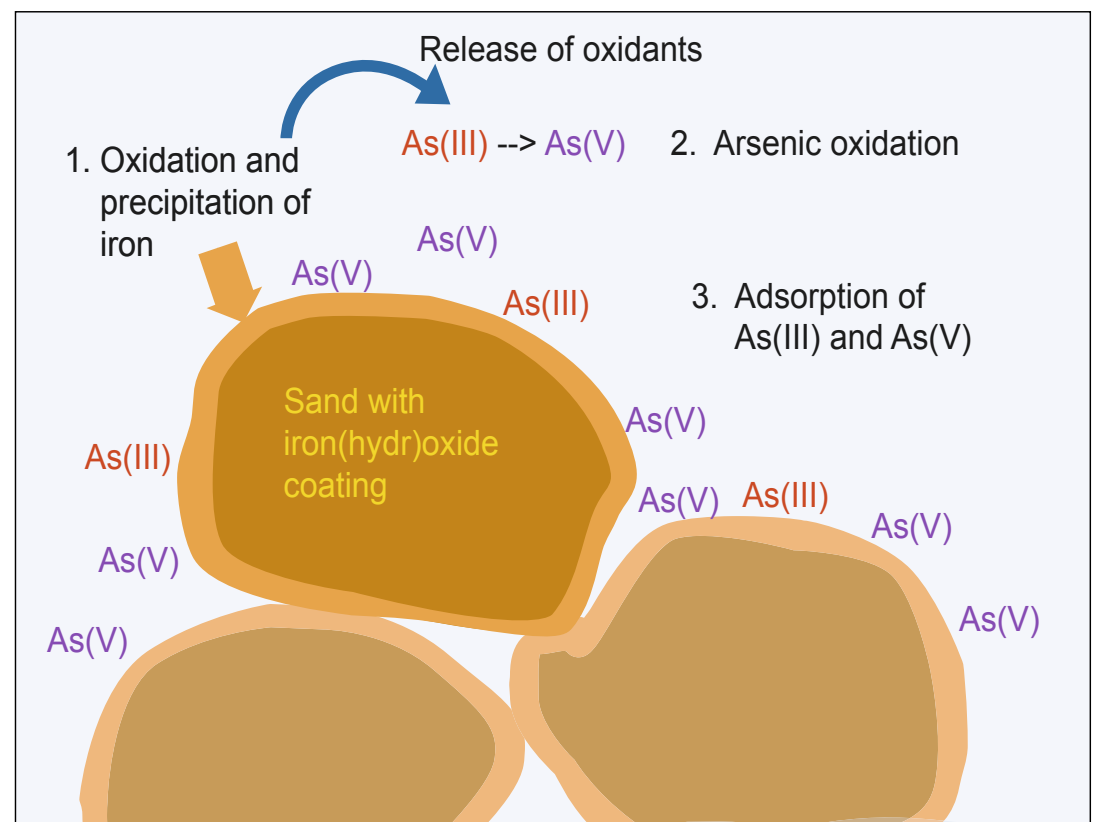

Fig. 8. Left: Design of a household sand filter that has been widely used in rural Vietnam for the removal of Fe and As from iron-reducing groundwater. The sand container serves as filter and the underlying tank is used to store treated water. Right: Illustration of the main processes involved in As oxidation and adsorption to $\mathrm{Fe}($ (II)(hydr)oxide coatings on sand grains.

Initially, dissolved $\mathrm{Fe}(\mathrm{II})$ is oxidized by oxygen to $\mathrm{Fe}(\mathrm{III})$, which quickly forms insoluble Fe(III)(hydr)oxides that coat the sand grains. Subsequently, such coatings catalyze further oxidation and precipitation of $\mathrm{Fe}$. The oxidation of Fe(II) triggers the formation of reactive oxygen species, such as hydroxy radicals, which can oxidize As(III) to more strongly adsorbable As(v). ${ }^{[43]}$ As(V) and - to a lesser extent - As(III) then adsorb to the coated sand particles where As remains immobilized under oxic conditions. In other words, a sand filter reverses the process of As release occurring in anoxic groundwater.

Arsenic removal in Bangladesh has turned out to be more challenging for various reasons. One reason is economic and political: The large cities of Dhaka and Chittagong are not affected, because they are located on Pleistocene terraces with low dissolved As concentrations in groundwater. Strongly affected are the rural regions of Bangladesh, where the water supply is decentralized and infrastructures for water treatment and As removal are not available. An important difference for As removal is the chemical composition of the groundwater: Natural Fe(II) concentrations (which help As removal) are, on average, much lower in Bangladesh than in Vietnam; and the concentrations of phosphate $\left(\mathrm{PO}_{4}{ }^{3-}\right)$, which competes with arsenate for adsorption and removal, are high. The relative concentrations and the consequence for As-removal are illustrated in Fig. 9.
Bangladesh because $\mathrm{Fe}$ (II) concentrations were too low and competing phosphate concentrations were often too high. ${ }^{[46]}$ What was needed was an additional source of $\mathrm{Fe}$ (II) or Fe(III) and an oxidant.

In a detailed study on the oxidation of $\mathrm{Fe}(\mathrm{II})$ in aerated As(III)-containing water, ${ }^{[43]}$ we discovered that As(III) is cooxidized with the oxidation of $\mathrm{Fe}(\mathrm{II})$ by dissolved $\mathrm{O}_{2}$. A reaction scheme derived from kinetic modeling is shown in Fig. 10. [43] At circumneutral $\mathrm{pH}$, predominantly $\mathrm{Fe}(\mathrm{IV})$, instead of ${ }^{\bullet} \mathrm{OH}$, is formed in the Fenton reaction. $\mathrm{Fe}$ (IV) is a more selective oxidant for $\mathrm{As}(\mathrm{III})$ than ${ }^{\circ} \mathrm{OH}$, but it also reacts with $\mathrm{Fe}(\mathrm{II})$. The oxidation of As(III) in groundwater with initially present Fe(II) is limited to about $30 \%$. A higher fraction of As(III) can be oxidized when $\mathrm{Fe}(\mathrm{II})$ is added in several smaller portions. Optimal oxidation is achieved by continuous slow addition of Fe(II) to keep steady state concentrations of $\mathrm{Fe}$ (II) low, so that $\mathrm{Fe}$ (IV) predominantly reacts with As(III).

\subsubsection{As-removal with Metallic (Zero-valent) Iron}

Instead of the slow addition of Fe(II), metallic iron (zerovalent iron, ZVI) is an ideal continuous source of Fe(II) when in contact with a flow of carbonate-containing oxic water at $\mathrm{pH}$ 7.0. ${ }^{[47]} \mathrm{As}$ (III) can be efficiently oxidized and sorbed on forming $\mathrm{Fe}(\mathrm{III})$ (hydr)oxides by treatment with ZVI in batch reactors or 


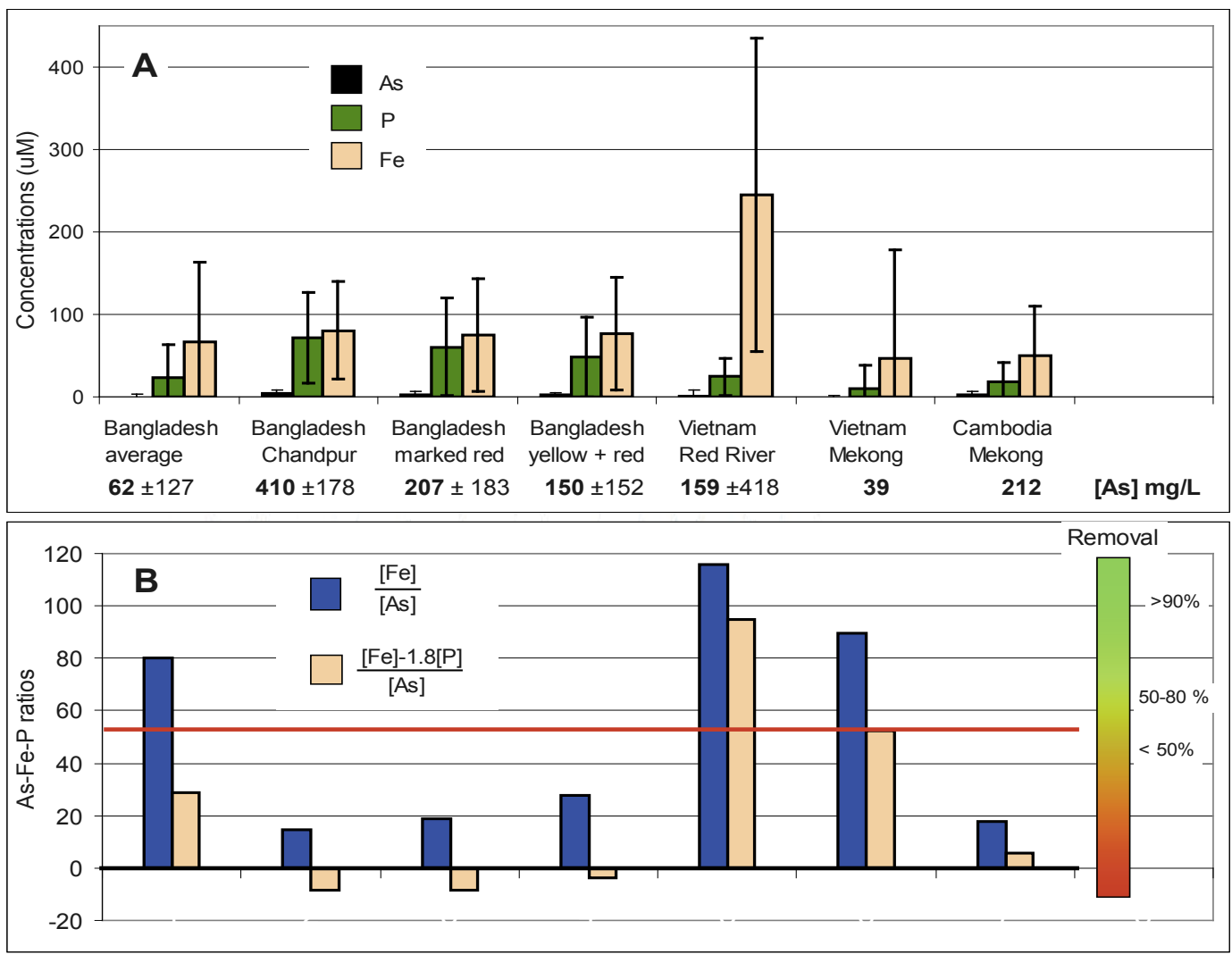

Fig. 9. Differences in Fe(II) and phosphate concentrations in groundwater in Bangladesh and Vietnam and the resulting effects on As removal. A: molar concentrations of As, $\mathrm{P}$ (phosphate) and $\mathrm{Fe}(\mathrm{Fe}(\mathrm{II}))$. B: molar ratio of [Fe]/ [As] (blue bars) and Fe available for As removal (brown bars) left after phosphate is precipitated $(1.2-1.8 \mathrm{Fe}$ is needed to precipitate one $\mathrm{P}$, depending on $\mathrm{Ca}$ concentrations). In the most affected regions in Bangladesh, Fe concentrations are too low for both $\mathrm{P}$ and As removal. Figure from Hug et al. [44]

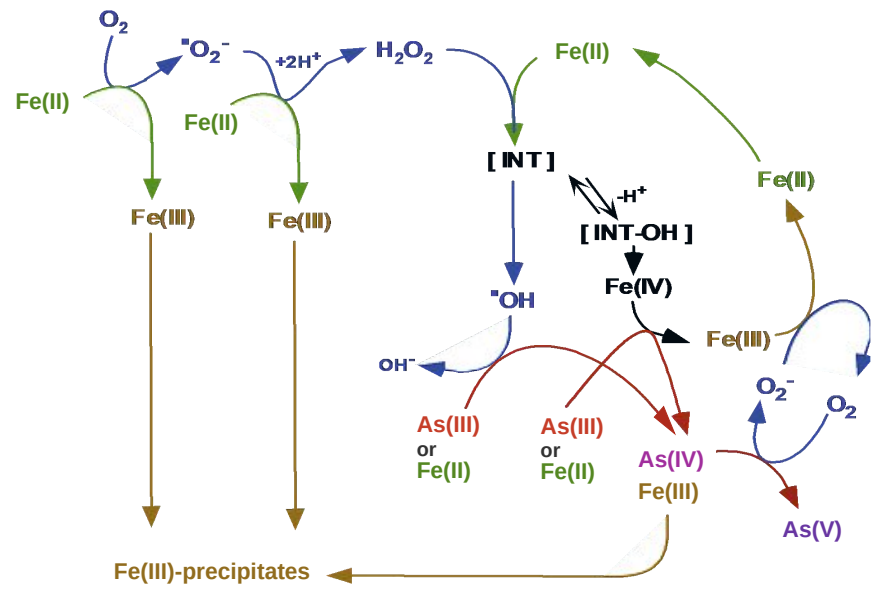

Fig. 10. Co-oxidation of $\mathrm{As}(\mathrm{III})$ with $\mathrm{Fe}(\mathrm{II})$. Dissolved $\mathrm{O}_{2}$ is reduced by $\mathrm{Fe}(\mathrm{II})$ in four steps, with formation of the intermediates ${ }^{\circ} \mathrm{O}_{2}^{-}, \mathrm{H}_{2} \mathrm{O}_{2}$ and $\cdot \mathrm{OH}$, whereby above $\mathrm{pH} 6$, predominantly $\mathrm{Fe}(\mathrm{IV})$ is formed in the reaction of $\mathrm{H}_{2} \mathrm{O}_{2}$ with $\mathrm{Fe}(I I)$ (Fenton reaction). With only initially present $\mathrm{Fe}(I I)$, the fraction of oxidized As(III) is limited by the competitive consumption of $\mathrm{Fe}(\mathrm{IV})$ by $\mathrm{As}(\mathrm{III})$ and $\mathrm{Fe}$ (II). Complete oxidation of $\mathrm{As}(\mathrm{III})$ to $\mathrm{As}(\mathrm{V})$ can be achieved by slow and continuous addition of Fe(II). Figure from Hug and Leupin. ${ }^{[43]}$

in columns (Fig. 11). ${ }^{[41,48]}$ ZVI columns can also remove other As species that can occur in groundwater, such as monothioarsenate. ${ }^{[49]}$

A successful filter, based on a layer of ZVI between two sand layers, the so-called SONO filter, was developed by Hussam and Munir. [50] Together with the producers of the SONO filters, we studied the influence of water composition and the mechanisms for As removal in new and old filters in field and laboratory studies (Fig. 12). [51] Over 400'000 filters have been produced and deployed in Bangladesh, but due to priorities given to deep tubewells as an alternative source of drinking water, the use of SONO filters has declined in recent years. ${ }^{[52]}$

\subsubsection{Structure and Arsenic-binding of Iron Precipitates}

The removal of As from drinking water, as well as the environmental cycling of As and its transfer into plants, largely depend on the binding of As onto Fe precipitates that dynamically form, transform and dissolve over redox transitions in aquifers and soils. The structure of Fe-precipitates formed by the oxygenation of anoxic waters is affected by solutes, such as phosphate and silicate, that interfere with Fe polymerization, as well as by major cations like $\mathrm{Ca}$ that modify the interactions between oxyanions and $\mathrm{Fe}$ and also alter the colloidal properties of the formed solids. A detailed mechanistic understanding of these processes is essential for the robust and targeted assessment of risks and the development of suitable mitigation strategies.

At Eawag, we performed extensive laboratory studies to assess how phosphate, silicate, and $\mathrm{Ca}$ interdependently affect the formation of $\mathrm{Fe}$ oxidation products and their transformation over time, and assessed the consequences for As removal by oxidation and precipitation of dissolved $\mathrm{Fe}(\mathrm{II}),{ }^{[53]}$ for As retention by $\mathrm{Fe}$ oxidation products upon aging, ${ }^{[54]}$ and for As removal in sand filters. ${ }^{[55]}$ Some key findings are summarized in Fig. 13a: When dissolved $\mathrm{Fe}^{2+}$ is oxidized in phosphate-containing water, phosphate strongly interferes with $\mathrm{Fe}(\mathrm{III})$ polymerization and induces the formation of amorphous Fe(III)-phosphate with limited As uptake capacity. Ca-Fe-phosphate formed in $\mathrm{Ca}$ - and $\mathrm{P}$-containing water incorporates more $\mathrm{P}$ per $\mathrm{Fe}$, which consequently also favors As removal. Furthermore, $\mathrm{Ca}-\mathrm{Fe}$-phosphate is more stable over time than Fe-phosphate, positively affecting As sequestration in the longer term. In water with low initial phosphate concentrations, or after depletion of dissolved phosphate by $(\mathrm{Ca}-)$ $\mathrm{Fe}(\mathrm{III})$-phosphate formation, silicate promotes the formation of ferrihydite-type solids with high oxyanion sorption capacity and inhibits the formation of more crystalline Fe oxides with lower sorption capacity. Thereby, silicate enhances As uptake and retention by Fe solids formed at lower initial $\mathrm{P} / \mathrm{Fe}$ ratios in solution. ${ }^{[54]}$ As shown in Fig. 13b, the effects of $\mathrm{P}, \mathrm{Ca}$ and $\mathrm{Si}$ on precipitate structure are reflected in substantial variations in As(v) removal efficiency and orders-of-magnitude differences in residual dis- 

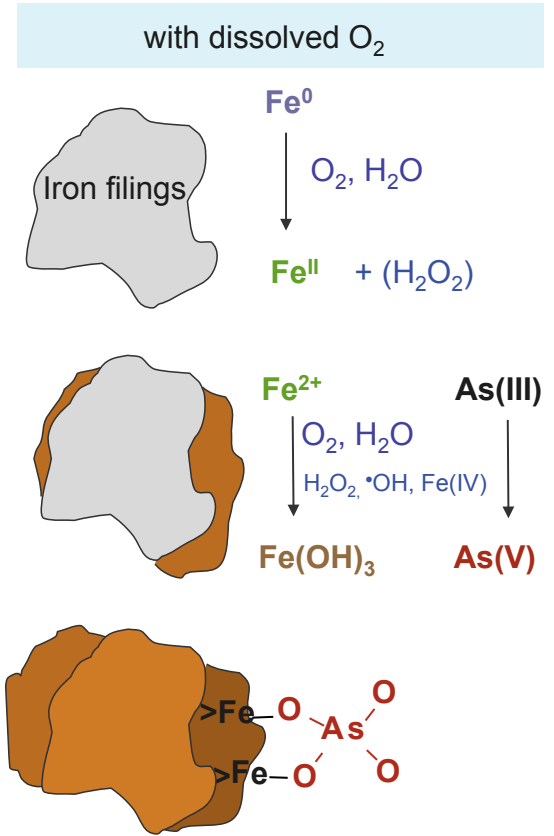

As sorbed on voluminous $\mathrm{Fe}(\mathrm{III})($ hydr)oxides

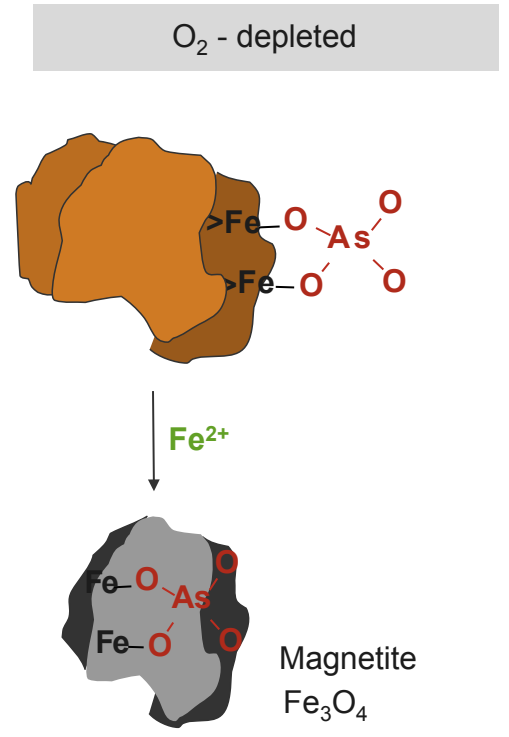

Fig. 11. Metallic zero-valent iron $(\mathrm{ZVI})$ as a source of $\mathrm{Fe}(\mathrm{II})$ and oxidants and Fe(III)(hydr)oxides for As removal. Corrosion of ZVI in contact with flowing oxic water leads to continuous formation of $\mathrm{Fe}(\mathrm{II})$ and low concentrations of $\mathrm{H}_{2} \mathrm{O}_{2}$ and oxidants such as $\mathrm{Fe}(\mathrm{IV})$ which efficiently oxidize As(III). As(v) is sorbed on continuously forming $\mathrm{Fe}($ (II)(hydr)oxide phases. Under stagnant conditions, dissolved $\mathrm{O}_{2}$ is depleted and $\mathrm{Fe}(\mathrm{III})$ phases are transformed to mixed $\mathrm{Fe}(\mathrm{II}, \mathrm{III})$ phases. Magnetite with incorporated $\mathrm{As}(\mathrm{V})$ was found to be the stable end product.

As sorbed in dense magnetite

solved As(v) concentrations after As(v) removal by Fe oxidation and precipitation.

\subsection{Alternative Water Resources, Deep Tubewells, High Concentrations of Manganese}

Amongst various mitigation options, ${ }^{[56]}$ deep tubewells have become the preferred and government-recommended option in Bangladesh. Deep tubewells were defined as tubewells screened below the clay layer (often 110-130 m deep in the central and southern regions) separating the Holocene from the Pleistocene aquifers in Bangladesh. Brown sediments, indicating the presence of $\mathrm{Fe}(\mathrm{III})$ (hydr)oxides have usually been targeted as As-safe sediments. However, the composition of groundwater as a function of depth is complex. In the area of Bangladesh where we conducted the rice field studies, we found high Mn concentrations of $2-5 \mathrm{mg} / \mathrm{L}$ in water from brown sediments. Mn concentrations $>0.4 \mathrm{mg} / \mathrm{L}$ can be neurotoxic, particularly to children. ${ }^{57]}$ Manganese removal procedures are available and are applied in industrialized countries, as reviewed in several articles.[41,58,59] However, most of these Mn-removal technologies are not applicable in rural regions of Bangladesh and elsewhere for the removal of Mn alone. The goal, therefore, was to find a depth range for deep tubewells in which both As and Mn concentrations are low. In a $2 \times 2 \mathrm{~km}^{2}$ area around the field site, the optimal depth was

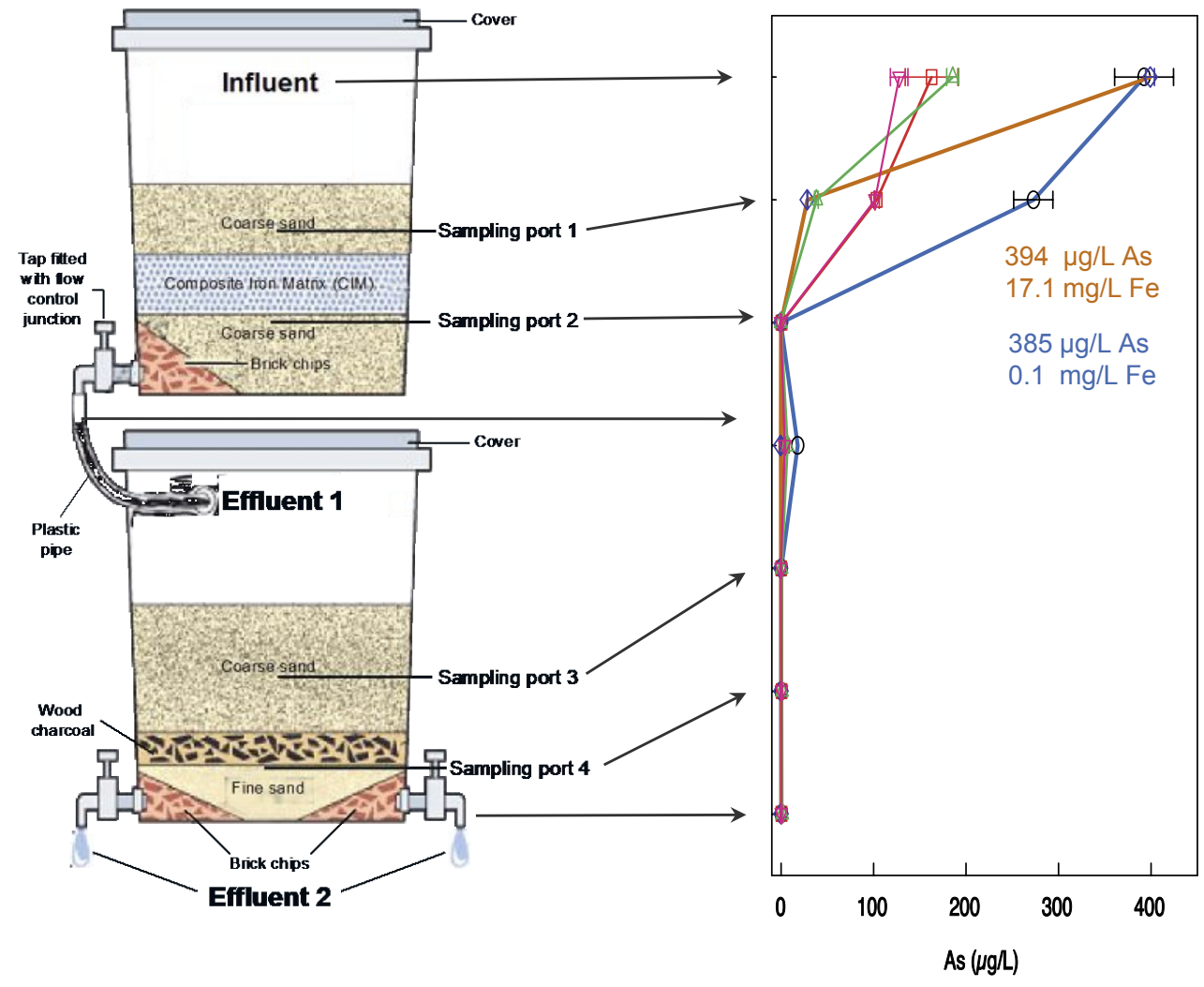

Fig. 12. Arsenic removal with ZVI-based iron and sand (SONO) filters. The upper bucket contains the active composite iron matrix (CIM) consisting of millimetersized iron scrap particles, located between two layers of sand. In water with high $\mathrm{Fe}$ (II) concentrations, As is partly removed in the upper sand layer. From all tested waters with various $\mathrm{As}, \mathrm{Fe}, \mathrm{P}$ and Ca concentrations, As was removed to $>95 \%$ in the CIM layer and in the subsequent bucket (filled with sand to remove residual particles) to below the Bangladesh limit of $50 \mu \mathrm{g} / \mathrm{L}$ and mostly also to below $10 \mu \mathrm{g} / \mathrm{L}$. Figure adapted from Neumann et al. ${ }^{[51]}$ 
Fig. 13. a) Schematic polyhedral representation of major types of Fe oxidation products: At initial dissolved molar $\mathrm{P} / \mathrm{Fe}$ ratios $>0.4$, mainly amorphous $\mathrm{Fe}(\mathrm{III})-$ phosphate forms, and structural uptake of $\mathrm{Ca}$ enhances $\mathrm{P}$ uptake and precipitate stability. At $\mathrm{P} / \mathrm{Fe}$ ratios $<0.6$, formation of $\mathrm{Fe}$ (III)phosphate is followed by the formation of P-free $\mathrm{Fe}$ (III)-precipitates in $\mathrm{P}$-depleted solution, with $\mathrm{Si}$ causing the formation of $\mathrm{Si}-$ containing ferrihydrite with higher $\mathrm{P}$ and $\mathrm{As}(\mathrm{v})$ sorption capacity than lepidocrocite forming in Si-free water. b) Residual As(v) in solutions with initially $500 \mu \mathrm{g} / \mathrm{L} \mathrm{As}(\mathrm{v})$ after oxidation and precipitation of $0.5 \mathrm{mM} \mathrm{Fe}$ as a function of initial $\mathrm{P} / \mathrm{Fe}$ ratio in solution, for electrolytes without/with $\mathrm{Ca}$ and $\mathrm{Si}$. Both $\mathrm{Ca}$ and $\mathrm{Si}$ cause substantially lower residual dissolved As(v) concentrations over certain ranges in $\mathrm{P} / \mathrm{Fe}$, reflecting their impact on precipitate structure and on As(v) uptake. Fig. 13b adapted from Senn et al. ${ }^{[54]}$ a)

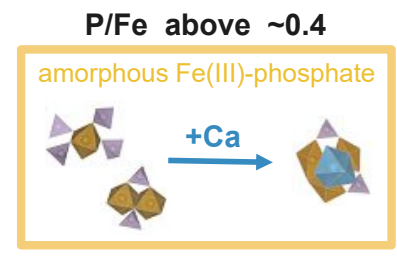

P/Fe below $\sim 0.6$

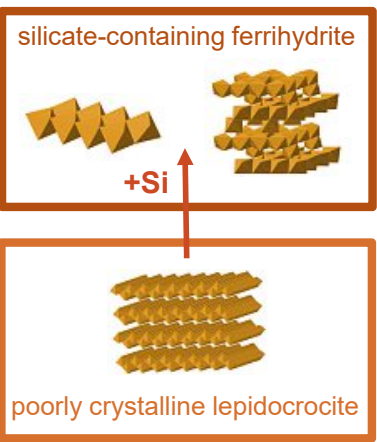

b)

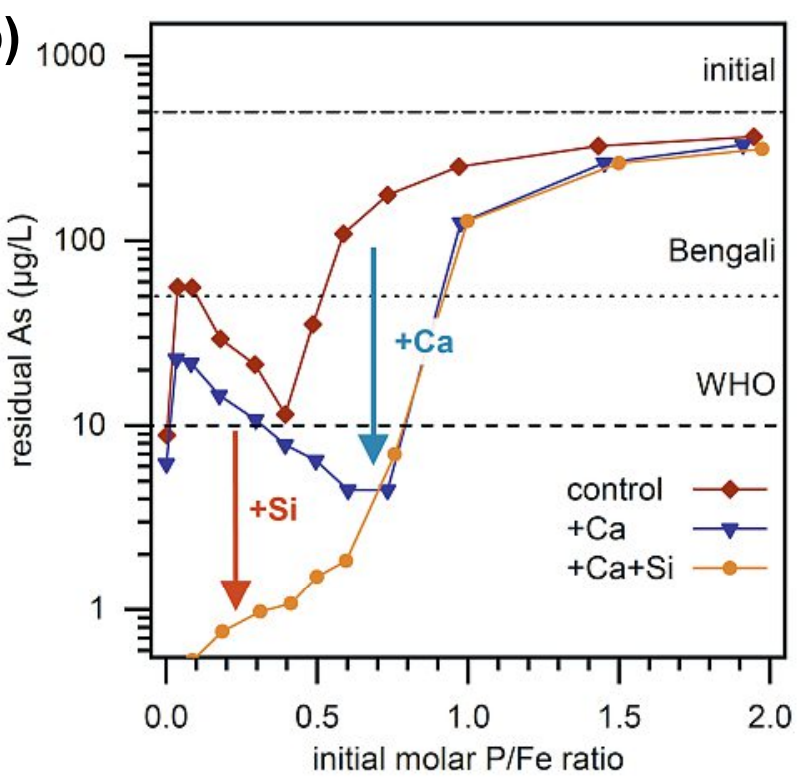

150-180 m, with light-grey to white sediments, ${ }^{[60]}$ but the optimal depth varies from region to region. The quality of water in deep sediments and different layers has been subsequently studied in more detail by other researchers; ${ }^{[61]}$ however, finding the optimal depth for tubewells is still a challenge for drillers. High concentrations of Mn have also been detected in Cambodia ${ }^{[15]}$ and Peru. ${ }^{[35]}$

\subsection{Meeting Drinking Water Limits for As in Switzerland}

Elevated levels of geogenic elements also occur in Switzerland. Until 2014, the limit for As in drinking water in Switzerland was $50 \mu \mathrm{g} / \mathrm{L}$. Concentrations of As from $10-50 \mu \mathrm{g} / \mathrm{L}$ are quite frequently found in ground- and spring water in the alpine regions of Switzerland in the cantons of Grisons, Valais and Ticino.[62] Although As concentrations of up to several $100 \mu \mathrm{g} / \mathrm{L}$ may occur in springs used by private owners, concentrations in communal water supply stations rarely exceed $50 \mu \mathrm{g} / \mathrm{L}$. Where higher concentrations in communal water supplies have been reported, for example close to a gold mine in Astano, Ticino, the affected sources were no longer used and drinking water was supplied by other, non-affected communities. ${ }^{[63]}$

In 2014, the limit for As in drinking water in Switzerland was lowered to $10 \mu \mathrm{g} / \mathrm{L}$, to be compliant with the limits recommended by the WHO and applied in most countries. At the same time, a new limit for $\mathrm{U}$ of $30 \mu \mathrm{g} / \mathrm{L}$ in Swiss drinking water was introduced, consistent with the limits in most countries.

With the new limits, concentrations of As and U were too high in a substantial number of communal water supplies. In 89 out of 1297 water samples from water sources in Valais, As concentrations exceeded $10 \mu \mathrm{g} / \mathrm{L} .{ }^{[64]}$ In 6 out of 5548 water samples collected across Switzerland, U exceeded $30 \mu \mathrm{g} / \mathrm{L}$. ${ }^{[62 \mathrm{a}]}$ As a consequence of the new limits, a few dozen water suppliers in Valais and Grisons were required to take measures to comply with the limits, either by treatment or by finding alternative sources of water.

To assist water suppliers in selecting optimal treatment methods, Eawag and the Swiss Gas and Water Industry Association (SVGW) studied methods for the removal of As and U in different waters and wrote a guideline with recommendations. ${ }^{[65]}$ To assess As and U removal in different waters, experiments were conducted with water from a community with $40-45 \mu \mathrm{g} / \mathrm{L}$ As and 28-35 $\mu \mathrm{g} / \mathrm{L} \mathrm{U}$, ammended with different concentrations of $\mathrm{Ca}^{2+}$, $\mathrm{HCO}_{3}^{-}$, and $\mathrm{H}_{4} \mathrm{SiO}_{4}$. In most affected communities, the source waters are oxic and As is present as $\mathrm{As}(\mathrm{V})$ and $\mathrm{U}$ as $\mathrm{U}(\mathrm{VI})$. An oxidation step is, therefore, not necessary. While As removal by adsorption to commercial $\mathrm{Fe}(\mathrm{III})$ (hydr)oxide adsorbents was not significantly influenced by water hardness, adsorption of U(VI) was stronger in soft water than in hard water. The reason for this is that $\mathrm{U}$ is present as negatively charged carbonate complexes, e.g., $\mathrm{UO}_{2}\left(\mathrm{CO}_{3}\right)_{2}{ }^{2-}$, which adsorb on $\mathrm{Fe}(\mathrm{III})$ (hydr)oxides, whereas neutral $\mathrm{Ca}_{2} \mathrm{UO}_{2}\left(\mathrm{CO}_{3}\right)_{3}$ complexes, formed at higher concentrations of $\mathrm{Ca}^{2+}$, adsorb only weakly. For water suppliers, the adsorption of $\mathrm{U}$ to $\mathrm{Fe}(\mathrm{III})$ (hydr)oxides causes serious problems, because these adsorbents cannot be regenerated and U concentrations can quickly exceed the radioactivity limits for disposal of spent adsorbents in designated land fill deposits. For these reasons, $\mathrm{U}$ is usually removed with anion exchange resins, which can be regenerated. For waters that contain both excessive As and U, a two-step treatment is applied: $U$ is removed first with a filter column containing anion exchanger, followed by a column containing Fe(III)(hydr)oxides for As removal, as shown in Fig. 14.

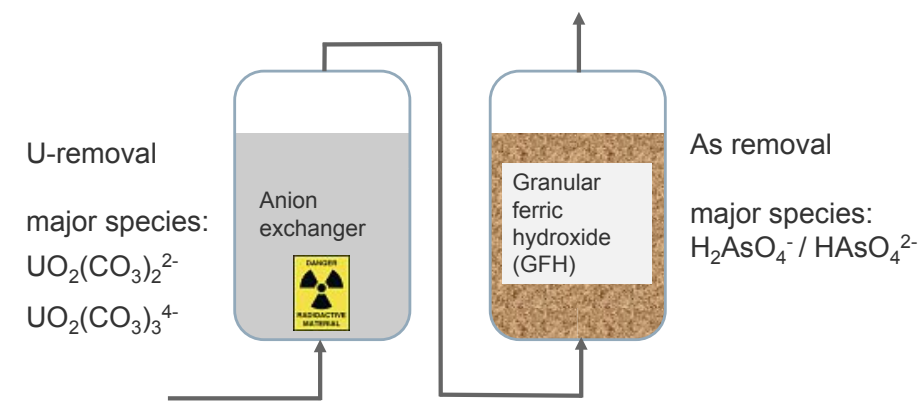

Fig. 14. Two-stage removal of As and $\mathrm{U}$ : Strongly basic anion resins can remove $U$ efficiently up to loadings of $>50 \mathrm{~kg} / \mathrm{m}^{3}$, but transport for regeneration is only allowed for materials with $U$ contents up to $10 \mathrm{~kg} / \mathrm{m}^{3}$. To prevent accumulation of $U$ in the column for As removal, removal of $U$ might be required even if $U$ in water is much below $30 \mu \mathrm{g} / \mathrm{L}$. 
A community in Switzerland that took exemplary measures to remove As from up to $40 \mu \mathrm{g} / \mathrm{L}$ und $\mathrm{U}$ from up to $25 \mu \mathrm{g} / \mathrm{L}$ in source waters to concentrations well below the limits in their drinking water supply is Grächen. ${ }^{[66]}$ However, for As removal in other communities, even U concentrations several times below the limit of $30 \mu \mathrm{g} / \mathrm{L}$ can make a U-removal step necessary to avoid problems with As removal. Several water suppliers in Switzerland have thus carefully evaluated the relative costs of water treatment and alternative options, such as piping water from more distant sources or supplying small numbers of affected people with bottled water. $[67,68]$

\section{Fluoride in Groundwater: Risk Maps and Fluoride Removal}

Fluoride in drinking water has a different history than As, as low concentrations in drinking water are beneficial. To prevent caries, fluoride has been added to drinking water in concentrations of, typically, 0.5-1.0 mg/L since the 1940s in the US and in many countries. However, the optimal range of concentrations for caries prevention is quite narrow. Addition of fluoride to drinking water was and is controversial, and many countries instead add fluoride to essential food supplements, typically to table salt. Concentrations of fluoride in drinking water in the higher $\mathrm{mg} / \mathrm{L}$ range lead to dental and skeletal fluorosis.

\subsection{Regional and Global Risk Maps for Elevated Concentrations of Fluoride}

High F concentrations on a global scale have been reviewed in several articles. ${ }^{[69-71]}$ According to these, F occurs mainly in igneous intrusive and extrusive rocks as fluorite $\left(\mathrm{CaF}_{2}\right)$, in concentrations of 20-3600 ppm, and also as fluoroapatite $\left(\mathrm{Ca}_{5}\left(\mathrm{PO}_{4}\right)_{3} \mathrm{~F}\right)$, micas, amphiboles and other minerals. High $\mathrm{F}$ concentrations thus occur in regions with underlying igneous and metamorphic rocks, and/or volcanic activity, combined with conditions favoring release of dissolved fluoride into groundwater, such as arid and semiarid (high $\mathrm{pH}$ ) conditions. Areas where high $\mathrm{F}$ concentrations were found include the Pacific volcanic belt, cratonic areas in central Africa, Asia, and North and South America, the East African Rift Valley, large sedimentary basins in South America, China and arid regions in the Southwest of the US and in Mexico. ${ }^{[72]}$ Since $\mathrm{CaF}_{2}$ is the main source of $\mathrm{F}$, high fluoride concentrations occur in groundwater with low $\mathrm{Ca}^{2+}$ concentrations at high $\mathrm{pH}$ where $\mathrm{Na}^{+}$and $\mathrm{HCO}^{3-}$ dominate. ${ }^{[71 b]}$ F-rich minerals and conditions that lead to the release of fluoride to water have been taken into account in the development of fluoride risk maps. GIS-based information on granitic, sedimentary and volcanic rocks with high F contents, coupled with conditions for high $\mathrm{pH}$ below alkaline soils and high ratios of evapotranspiration over precipitation rates, indicate (among other factors) a high risk for fluoride contamination. Similarly as done for As, a global risk map for fluoride ${ }^{[73]}$ was developed using a geospatial modeling approach (see Fig. 15).[73] Our global and regional risk maps are openly accessible on the GIS-based interactive Groundwater Assessment Platform (GAP, www.gapmaps.org).[74]

\subsection{Fluoride Removal}

In order to remove $\mathrm{F}$ from water, various methods, such as adsorption on aluminum oxides, ${ }^{[75]}$ co-precipitation with aluminum oxide precipitates formed by the addition of $\mathrm{Al}_{2}\left(\mathrm{SO}_{4}\right)_{3}$ and lime (Nalgonda technique), ${ }^{[76]}$ electrocoagulation, ${ }^{[77]}$ synthetic and natural ion exchange resins, ${ }^{[78]}$ and membranes have been described and can be applied if the necessary materials and infrastructure are available.

Similarly to the situation with As, we aimed to develop methods that are able to remove fluoride with locally available materials. In low-income rural regions, the challenge is to find lowcost and locally available adsorbents. ${ }^{[79]}$ Annette Johnson and her group, together with scientists from Ethiopia, Burkina Faso, Kenya, and India have studied the applicability of bone char (consisting of hydroxyapatite (HAP) and other phosphates), which can be produced at low cost by calcination of animal bones at 400$600{ }^{\circ} \mathrm{C}$. They studied fluoride removal with bone char in detail[80] and tested the applicability for fluoride removal from drinking water in field studies, for example in Burkina Faso. ${ }^{[81]}$ Due to its composition and structure, bone char as well as synthetic HAP, efficiently remove fluoride by exchange with surface and partly structural hydroxyl groups:

$$
\mathrm{Ca}_{10}\left(\mathrm{PO}_{4}\right)_{6}(\mathrm{OH})_{2}+2 \mathrm{~F}^{-} \rightarrow \mathrm{Ca}_{10}\left(\mathrm{PO}_{4}\right)_{6} \mathrm{~F}_{2}+2 \mathrm{OH}^{-}
$$

It was demonstrated that bonechar can be produced locally, that its application is well accepted, and that safe fluoride concentration below $1.5 \mathrm{mg} / \mathrm{L}$ can be reached with bonechar filters. ${ }^{[81]}$ However, due to often high fluoride concentrations (up to $26 \mathrm{mg} / \mathrm{L}$ in Ethiopia ${ }^{[81]}$ ) bone char is usually exhausted after the filtration of only a few hundred bed volumes and then needs to be replaced. To prolong the lifetime of bone-char filters, Annette Johnson and her group tested the addition of calcium phosphate. With careful optimization of the composition and the shape of added phosphate
Step 1.

Collecting data

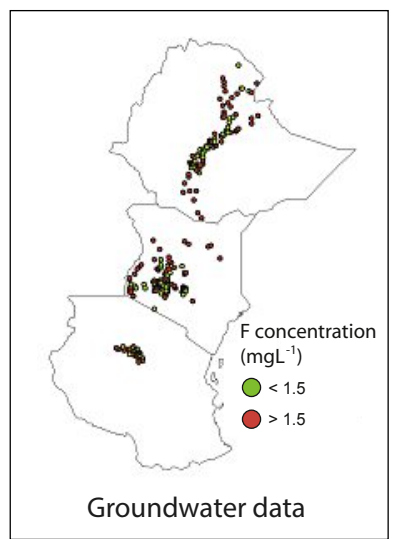

Step 2.

Geo-statistical modeling
Step 3.

Identifying risk areas
Step 4.

Undertaking action

Fig. 15. Schematic illustration of the steps involved in geospatial prediction modeling using the example of groundwater fluoride in Ethiopia, Kenya

and Tanzania (African Rift Valley).

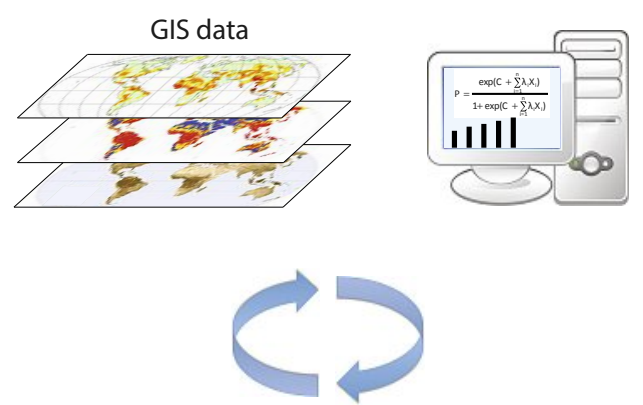

Combining geochemical and statistical expertise
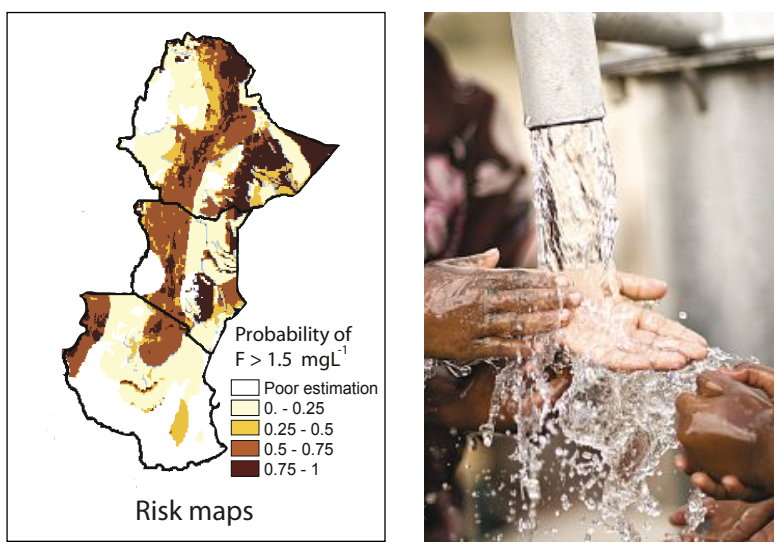
pellets, the dissolution kinetics matched the continuous formation of new HAP (Fig. 16), and the lifetime of experimental filters could be extended to over 2500 bed volumes (manuscripts in preparation).

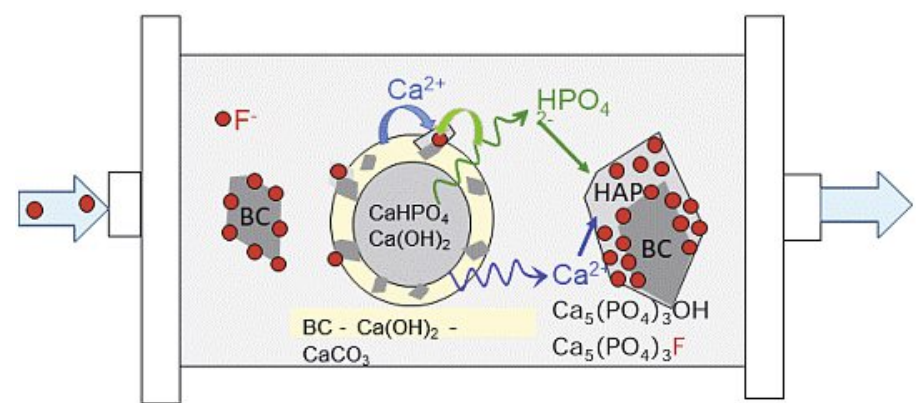

Fig. 16. Fluoride removal with contact precipitation. BC: bone char (HAP), with adsorption of $\mathrm{F}^{-}$and dissolution of $\mathrm{CaHPO}_{4} / \mathrm{Ca}(\mathrm{OH})_{2}$ pellets leading to precipitation of more HAP and incorporation of $\mathrm{F}^{-}$.

\section{Applicability and Acceptability of Mitigation Options, Challenges}

Although this article is focused on science and technology, the success of water treatment methods and other mitigation options depends not only on scientific and engineering considerations, but also on social and economic factors. Eawag carries out research on all aspects of water-related issues and serves as a bridge between research and practice. With its interdisciplinary culture (70\% natural sciences, $25 \%$ engineering sciences, $5 \%$ social sciences), Eawag is well positioned to cover the range of expertise required. In 2006, Annette Johnson initiated the Water Resource Quality (WRQ) project as an interdisciplinary collaboration of geochemists, engineers, and social scientists. The project encompassed regional assessments of geogenic contamination with analysis of water samples from field surveys, risk modelling, and the development and assessment of mitigation options and communication strategies to support local authorities and institutions. An important aspect of the project was studies on the social acceptability of mitigation options based on interviews, questionnaires, and application of the Protection Motivation and Planned Behavior Theory. ${ }^{\left[{ }^{[2]}\right.}$ Examples are surveys that rate the social acceptability of As removal methods and switching from inexpensive shallow wells to more expensive shared deep tubewells. ${ }^{[83-84]}$ Another example is studies on the user-acceptability of fluoride removal methods in rural Ethiopia. ${ }^{[86-88]}$ Among many publications, a combined output of the Eawag WRQ project (2006-2012) is the freely downloadable handbook (https://www.eawag.ch/en/ research/humanwelfare/drinkingwater/wrq/geogenic-contamination-handbook/). The handbook assists water suppliers, local governments, NGOs and all interested readers with recognizing, assessing and addressing geogenic pollution. ${ }^{[88 \mathrm{~b}]}$

In addition, the online Groundwater Assessment Platform (GAP) ${ }^{[74]}$ was developed with support of the Swiss Agency of Development and Cooperation (SDC) to enable free and interactive access to the risk maps of geogenic contamination on global and regional scales. The maps can alert stakeholders and water suppliers to possible contamination of groundwater in their areas. Where risks are indicated, water resources should be tested and appropriate measures taken. Most industrial countries have already tested their water sources and have installed water treatment plants before GAP existed. [40] However, in low-income countries with known large-scale and severe contaminations, such as in Bangladesh, India, Nepal, Cambodia, and in newly-indicated and verified regions in Peru, ${ }^{[35]}$ Bolivia or Burkina Faso, ${ }^{[34 b]}$ the provision of safe drinking water through water treatment or al- ternative water sources remains a challenge. In Bangladesh, 20 million people are still consuming water with As concentrations of hundreds of $\mu \mathrm{g} / \mathrm{L}$. Deep tubewells were not installed in sufficient numbers in some of the most affected regions or do not provide water of acceptable quality. Locally produced SONO filters reached a distribution of around 300'000 a few years ago, but this number stagnated and declined due to lack of promotion and funding and, partly, acceptability. ${ }^{[52]}$ Further challenges are, for example, that Fe nail filters used in Nepal are currently not sufficiently efficient in removing As to the limits of 10 or $50 \mu \mathrm{g} / \mathrm{L}$. [89] RemotevillagesinaridregionsofAfrica-forexampleinBurkinaFaso - often have only one well with As concentration up to $1000 \mu \mathrm{g} / \mathrm{L}^{[90]}$ and lacking availability of commercial adsorbents or chemicals for water treatment. Researchers at many institutions continue to develop or optimize existing water treatment methods. For the removal of As, application of $\mathrm{Fe}$ in the form of nails, wire or $\mathrm{Fe}$ scrap, which are available at low cost virtually everywhere, is one of the more promising options. However, filter designs still have to be optimized for robustness and reliability with minimal maintenance. For fluoride removal, the application of bonechar or synthetic HAP, in combination with contact precipitation, is promising and needs to be further developed and optimized. Current projects are usually collaborations between scientists at universities in affected regions with scientists in industrialized countries. This allows for an optimal exchange of expertise and a combination of field and laboratory studies and measurements with advanced instrumentation. As a result of the combined efforts of researchers and non-academic partners, significant progress has been made over the last decades to ensure access to drinking water that is largely free of geogenic contaminants. However, further efforts on national and international levels are still required to meet the target of the UN Sustainable Development Goal 6 to provide access to safe drinking water for all by 2030 .

\section{Acknowledgements}

The work described in this article would not have been possible without the input of numerous researchers at Eawag and other institutions in Switzerland and abroad. Without being able to be complete, and with apologies to those who could not be listed due to space restrictions, we would like to thank several groups of people. 1) Current and former Eawag researchers: Karim Abbaspour, Manouchehr Amini, Dahyann Araya, AuA team, Hans-Peter Bader, Jakov Bolotin, Paul Borer, Anja Bretzler, Irene Brunner, Johanna Buschmann, Silvio Canonica, Olaf Cirpka, Caroline de Meyer, Felix Frei, Dominique Gärtner, Walter Giger, Janet Hering, Eduard Höhn, Jennifer Inauen, Rick Johnston, Ralf Kägi, Ioannis Katsoyiannis, Stephan Klump, Rolf Kipfer, David Kistler, Madeleine Langmeier, Ursula Lindauer, Christoph Lüthi, Samuel Luzi, Hermann Mönch, Hans-Joachim Mosler, Kim Mueller, Harald Neidhardt, Anke Neumann, Lars Osterwalder, Numa Pfenninger, Joel Podgorski, Linda Roberts, Luis Rodriguez-Lado, Thomas Rosenberg, Helen Rowland, Thomas Rüttimann, Ruth Scheidegger, Roland Schertenleib, Anna Senn, Mario Schirmer, Ursula Schönenberger, Laura Sigg, Caroline Stengel, Ralph Sonderegger, Emiliano Stopelli, Robert Tobias, Yama Tomonaga, Jan Roelof van der Meer, Urs von Gunten, Martin Wegelin, Hanbin Xue, Hong Yang, Jürg Zobrist, Christian Zurbrügg. We also thank Walter Giger for his support and for our nomination for the Sandmeyer Award. We are particularly grateful to Janet Hering and to the directorate of Eawag for their continuous support.

2) International collaborators: Tran Hong Con, Vi Mai Lan, Pham Kim Trang, Pham Hung Viet (CETASD Vietnam); Mickey Sampson (RDIC Cambodia); Borhan Badruzzaman, Ashraf Ali, Ganesh Saha (BUET Bangladesh); Kazi Matin Ahmed (U. Dhaka); Guifan Sun, Qiang Zhang, Quanmei Zheng (China Medical U); Riyutaro Otsuka, Chiho Watanabe (U Tokio); David Polya, Jon Lloyd (U Manchester); Ruben Kretzschmar, Bernhard Wehrli, Jessica Dittmar (ETHZ); Lex van Geen, Benjamin Bostick (Columbia University); Charles Harvey, Rebecca Neumann (MIT); Doris Stüben, Thomas Neumann, Eli Eiche (KIT Karlsruhe); Ali Eqani (Pakistan); Pawan Labhasetwar, Dipankar Saha (India); Juan Rodriguez (Peru); Ingo Wahnfried (Brazil); Andreas Kappler, Katja Nitzsche (U Tübingen); Joey Rawson, Bhasker Rathi, Ilka Wallis, Henning Prommer (Australia). 
We acknowledge substantial external funding from the Swiss Agency for Development and Cooperation, the Swiss National Science Foundation, the Alliance for Global Sustainability, and the European Commission Marie Skłodowska-Curie Actions.

Received: June 12, 2020

[1] Sustainable Development Goal 6, https://sustainabledevelopment.un.org/ sdg6, https://undocs.org/E/2019/68.

[2] I. A. Shiklomanov, in 'Water in crisis: a guide to the world's fresh water resources', Ed. P. H. Gleick, Oxford University Press, New York, 1993, p. 13.

[3] J. Van der Gun, U. W. W. A. Programme, 'Groundwater and global change: trends, opportunities and challenges', United Nations Educational, Scientific and Cultural Organization, 75352 Paris 07 SP, France, 2012.

[4] a) S. Murcott, 'Arsenic Contamination in the World - An International Sourcebook', IWA Publishing, London SW1H 0QS, UK, 2012; b) J. Podgorski, M. Berg, Science 2020, 368, 845, DOI: 10.1126/science. aba1510.

[5] WHO, 1984, Second ed., vol. 2. World Health Organization, Geneva, 1984.

[6] J. E. Podgorski, P. Labhasetwar, D. Saha, M. Berg, Environ. Sci. Technol. 2018, 52, 9889, DOI: 10.1021/acs.est.8b01679.

[7] a) R. Nickson, J. McArthur, W. Burgess, K. Matin Ahmed, P. Ravenscroft, M. Rahman, Nature 1998, 395, 338, DOI: 10.1038/26387; b) R. T. Nickson, J. M. McArthur, P. Ravenscroft, W. G. Burgess, K. M. Ahmed, Appl. Geochem. 2000, 15, 403, DOI: 10.1016/S0883-2927(99)00086-4.

[8] D. G. Kinniburgh, P. L. Smedley, 'Arsenic contamination of groundwater in Bangladesh', B. G. S. Keyworth., 2001.

[9] A. H. Smith, E. O. Lingas, M. Rahman, Bull. WHO 2000, 78, 1093.

[10] S. J. S. Flora, 'Handbook of Arsenic Toxicology', Elsevier Inc., 2015.

[11] C. W. Schmidt, Environ. Health Persp. 2014, 122, A130, DOI: 10.1289/ ehp.122-A130.

[12] J. S. F. Swaran, 'Handbook of Arsenic Toxicology', Academic Press 2015.

[13] J. F. Ferguson, J. Gavis, Water Res. 1972, 6, 1259, DOI: 10.1016/00431354(72)90052-8.

[14] P. L. Smedley, D. G. Kinniburgh, Appl. Geochem. 2002, 17, 517, DOI: 10.1016/S0883-2927(02)00018-5.

[15] J. Buschmann, M. Berg, C. Stengel, M. L. Sampson, Environ. Sci. Technol. 2007, 41, 2146, DOI: 10.1021/es062056k.

[16] L. Winkel, M. Berg, C. Stengel, T. Rosenberg, Appl. Geochem. 2008, 23, 3019, DOI: 10.1016/j.apgeochem.2008.06.021.

[17] J. Buschmann, M. Berg, C. Stengel, L. Winkel, M. L. Sampson, P. T. K. Trang, P. H. Viet, Environ. Int. 2008, 34, 756, DOI: 10.1016/j.envint.2007.12.025.

[18] M. Berg, H. C. Tran, T. C. Nguyen, H. V. Pham, R. Schertenleib, W. Giger, Environ. Sci. Technol. 2001, 35, 2621, DOI: 10.1021/es010027y.

[19] a) M. Berg, C. Stengel, P. T. K. Trang, P. Hung Viet, M. L. Sampson, M. Leng, S. Samreth, D. Fredericks, Sci. Tot. Environ. 2007, 372, 413, DOI: 10.1016/j. scitotenv.2006.09.010; b) J. Buschmann, M. Berg, Appl. Geochem. 2009, 24 , 1278, DOI: 10.1016/j.apgeochem.2009.04.002.

[20] L. Winkel, M. Berg, M. Amini, S. J. Hug, C. A. Johnson, Nature Geosci. 2008, 1, 536, DOI: $10.1038 /$ ngeo 254 .

[21] L. R. Lado, D. Polya, L. Winkel, M. Berg, A. Hegan, Appl. Geochem. 2008, 23, 3009, DOI: 10.1016/j.apgeochem.2008.06.028.

[22] N. Yang, L. H. E. Winkel, K. H. Johannesson, Environ. Sci. Technol. 2014, 48, 5660, DOI: $10.1021 / \mathrm{es} 405670 \mathrm{~g}$

[23] J. D. Ayotte, B. T. Nolan, J. R. Nuckols, K. P. Cantor, G. R. Robinson Jr, D. Baris, L. Hayes, M. Karagas, W. Bress, D. T. Silverman, J. H. Lubin, Environ. Sci. Technol. 2006, 40, 3578, DOI: 10.1021/es051972f.

[24] M. Amini, K. C. Abbaspour, M. Berg, L. Winkel, S. J. Hug, E. Hoehn, H. Yang, C. A. Johnson, Environ. Sci. Technol. 2008, 42, 3669, DOI: 10.1021/ es702859e

[25] Q. Yang, H. B. Jung, R. G. Marvinney, C. W. Culbertson, Y. Zheng, Environ. Sci. Technol. 2012, 46, 2080, DOI: 10.1021/es203793x.

[26] Q. Yang, H. B. Jung, C. W. Culbertson, R. G. Marvinney, M. C. Loiselle, D. B. Locke, H. Cheek, H. Thibodeau, Y. Zheng, Environ. Sci. Technol. 2009, 43, 2714, DOI: 10.1021/es803141m.

[27] L. Rodri?uez-Lado, G. Sun, M. Berg, Q. Zhang, H. Xue, Q. Zheng, C. A. Johnson, Science 2013, 341, 866, DOI: 10.1126/science.1237484.

[28] A. Van Geen, K. H. Win, T. Zaw, W. Naing, J. L. Mey, B. Mailloux, Sci. Tot. Environ. 2014, 478, 21, DOI: 10.1016/j.scitotenv.2014.01.073.

[29] L. H. E. Winkel, P. T. K. Trang, V. M. Lan, C. Stengel, M. Amini, N. T. Ha, P. H. Viet, M. Berg, Proc. Natl Acad. Sci. USA 2011, 108, 1246, DOI: 10.1073/ pnas. 1011915108 .

[30] A. Van Geen, B. C. Bostick, P. Thi Kim Trang, V. M. Lan, N. N. Mai, P. D. Manh, P. H. Viet, K. Radloff, Z. Aziz, J. L. Mey, M. O. Stahl, C. F. Harvey, P. Oates, B. Weinman, C. Stengel, F. Frei, R. Kipfer, M. Berg, Nature 2013 501, 204, DOI: 10.1038/nature12444.

[31] I. Mihajlov, M. R. H. Mozumder, B. C. Bostick, M. Stute, B. J. Mailloux, P. S. K. Knappett, I. Choudhury, K. M. Ahmed, P. Schlosser, A. van Geen, Nature Commun. 2020, 11, 2244, DOI: 10.1038/s41467-020-16104-z.
[32] H. A. L. Rowland, E. O. Omoregie, R. Millot, C. Jimenez, J. Mertens, C. Baciu, S. J. Hug, M. Berg, Appl. Geochem. 2011, 26, 1, DOI: 10.1016/j. apgeochem.2010.10.006.

[33] J. E. Podgorski, S. A. M. A. S. Eqani, M. Berg, in 'Proceedings of Arsenic in the Environment', CRC Press/Balkema, 2018, p. 541, DOI: 10.1201/9781351046633-211.

[34] a) A. Bretzler, F. Lalanne, J. Nikiema, J. Podgorski, N. Pfenninger, M. Berg, M. Schirmer, Sci. Tot. Environ. 2017, 584-585, 958, DOI: 10.1016/j. scitotenv.2017.01.147; b) A. Bretzler, L. Stolze, J. Nikiema, F. Lalanne, E. Ghadiri, M. S. Brennwald, M. Rolle, M. Schirmer, Geosci. Front. 2019, 10 , 1685, DOI: 10.1016/j.gsf.2018.06.004.

[35] C. M. C. de Meyer, J. M. Rodríguez, E. A. Carpio, P. A. García, C. Stengel, M. Berg, Sci. Tot. Environ. 2017, 607-608, 1437, DOI: 10.1016/j.scitotenv.2017.07.059.

[36] a) L. C. Roberts, S. J. Hug, J. Dittmar, A. Voegelin, G. C. Saha, M. A. Ali, A. B. M. Badruzzaman, R. Kretzschmar, Environ. Sci. Technol. 2007, 41, 5960, DOI: 10.1021/es070298u; b) J. Dittmar, A. Voegelin, L. C. Roberts, S. J. Hug, G. C. Saha, M. A. Ali, A. B. M. Badruzzaman, R. Kretzschmar, Environ. Sci. Technol. 2007, 41, 5967, DOI: 10.1021/es0702972.

[37] a) J. Dittmar, A. Voegelin, F. Maurer, L. C. Roberts, S. J. Hug, G. C. Saha, M. A. Ali, A. B. M. Badruzzaman, R. Kretzschmar, Environ. Sci. Technol. 2010 44, 8842, DOI: 10.1021/es101962d; b) J. Dittmar, A. Voegelin, L. C. Roberts, S. J. Hug, G. C. Saha, M. A. Ali, A. B. M. Badruzzaman, R. Kretzschmar, Environ. Sci. Technol. 2010, 44, 2925, DOI: 10.1021/es903117r.

[38] L. C. Roberts, S. J. Hug, J. Dittmar, A. Voegelin, R. Kretzschmar, B. Wehrli, O. A. Cirpka, G. C. Saha, M. Ashraf Ali, A. B. M. Badruzzaman, Nature Geosci. 2010, 3, 53, DOI: 10.1038/ngeo723.

[39] B. L. Huhmann, C. F. Harvey, A. Uddin, I. Choudhury, K. M. Ahmed, J. M. Duxbury, B. C. Bostick, A. Van Geen, Environ. Sci. Technol. 2017, 51, 11553, DOI: $10.1021 /$ acs.est.7b01487.

[40] J. G. Hering, I. A. Katsoyiannis, G. A. Theoduloz, M. Berg, S. J. Hug, J. Environ. Eng. 2017, 143, DOI: 10.1061/(ASCE)EE.1943-7870.0001225.

[41] J. H. Bruins, B. Petrusevski, Y. M. Slokar, J. C. Kruithof, M. D. Kennedy, Desalin. Water Treat. 2015, 55, 1851, DOI: 10.1080/19443994.2014.927802.

[42] M. Berg, S. Luzi, P. T. K. Trang, P. H. Viet, W. Giger, D. Stüben, Environ. Sci. Technol. 2006, 40, 5567, DOI: 10.1021/es060144z.

[43] S. J. Hug, O. Leupin, Environ. Sci. Technol. 2003, 37, 2734, DOI: 10.1021/ es $026208 x$.

[44] S. J. Hug, O. X. Leupin, M. Berg, Environ. Sci. Technol. 2008, 42, 6318, DOI: $10.1021 /$ es7028284.

[45] a) M. Wegelin, D. Gechter, S. Hug, A. Mahmud, A. Motaleb, in WEDC Conference 2000, p. 255; b) S. J. Hug, L. Canonica, M. Wegelin, D. Gechter, U. von Gunten, Environ. Sci. Technol. 2001, 35, 2114, DOI: 10.1021/ es001551s.

[46] S. J. Hug, Environ. Sci. Int. J. Environ. Physiol. Toxicol. 2001, 8, 467.

[47] O. X. Leupin, S. J. Hug, Water Res. 2005, 39, 1729, DOI: 10.1016/j.watres.2005.02.012

[48] I. A. Katsoyiannis, T. Ruettimann, S. J. Hug, Environ. Sci. Technol. 2008, 42 , 7424.

[49] B. Planer-Friedrich, J. Schaller, F. Wismeth, J. Mehlhorn, S. J. Hug, Environ Sci. Technol. 2018, 52, 5931, doi.org/10.1021/acs.est.8b00948

[50] A. Hussam, A. K. M. Munir, J. Environ. Sci. Health A 2007, 42, 1869, DOI $10.1080 / 10934520701567122$

[51] A. Neumann, R. Kaegi, A. Voegelin, A. Hussam, A. K. M. Munir, S. J. Hug, Environ. Sci. Technol. 2013, 47, 4544, DOI: 10.1021/es305176x.

[52] D. K. Kundu, A. P. J. Mola, A. Gupta, Water Policy 2016, 18, 1490, DOI: 10.2166/wp.2016.014

[53] a) L. C. Roberts, S. J. Hug, T. Ruettimann, M. Billah, A. W. Khan, M. T Rahman, Environ. Sci. Technol. 2004, 38, 307, DOI: 10.1021/es0343205; b) A. Voegelin, R. Kaegi, J. Frommer, D. Vantelon, S. J. Hug, Geochim. Cosmochim. Acta 2010, 74, 164, DOI: 10.1016/j.gca.2009.09.020

[54] A. C. Senn, S. J. Hug, R. Kaegi, J. G. Hering, A. Voegelin, Water Res. 2018 131, 334, DOI: 10.1016/j.watres.2017.12.038

[55] A. Voegelin, R. Kaegi, M. Berg, K. S. Nitzsche, A. Kappler, V. M. Lan, P. T. K. Trang, J. Göttlicher, R. Steininger, Environ. Chem. 2014, 11, 566, DOI: 10.1071/EN14011

[56] M. F. Ahmed, S. Ahuja, M. Alauddin, S. J. Hug, J. R. Lloyd, A. Pfaff, T. Pichler, C. Saltikov, M. Stute, A. Van Geen, Science 2006, 314, 1687, DOI: 10.1126/science. 1133146

[57] a) D. Hafeman, P. Factor-Litvak, Z. Cheng, A. van Geen, H. Ahsan, Environ. Health Persp. 2007, 115, 1107, DOI: 10.1289/ehp.10051; b) K. Khan, P. Factor-Litvak, G. A. Wasserman, X. Liu, E. Ahmed, F. Parvez, V. Slavkovich, D. Levy, J. Mey, A. van Geen, J. H. Graziano, Environ. Health Persp. 2011, 119, 1501, DOI: 10.1289/ehp.1003397; c) K. Khan, G. A. Wasserman, X Liu, E. Ahmed, F. Parvez, V. Slavkovich, D. Levy, J. Mey, A. van Geen, J. H. Graziano, P. Factor-Litvak, NeuroToxicol. 2012, 33, 91, DOI: 10.1016/j. neuro.2011.12.002; d) M. F. Bouchard, S. Sauvé, B. Barbeau, M. Legrand, M. Brodeur, T. Bouffard, E. Limoges, D. C. Bellinger, D. Mergler, Environ. Health Persp. 2011, 119, 138, DOI: 10.1289/ehp.1002321.

[58] K. S. Subramanian, T. Viraraghavan, T. Phommavong, S. Tanjore, Water Qual. Res. J. Canada 1997, 32, 551. 
[59] a) R. Buamah, B. Petrusevski, D. de Ridder, T. S. C. M. van de Wetering, J. C. Shippers, Water Sci. Technol. Water Supp. 2009, 9, 89, DOI: 10.2166/ ws.2009.009; b) J. E. Tobiason, A. Bazilio, J. Goodwill, X. Mai, C. Nguyen, Curr. Poll. Rep. 2016, 2, 168, DOI: 10.1007/s40726-016-0036-2.

[60] S. J. Hug, D. Gaertner, L. C. Roberts, M. Schirmer, T. Ruettimann, T. M. Rosenberg, A. B. M. Badruzzaman, M. Ashraf Ali, Appl. Geochem. 2011, 26, 1077, DOI: 10.1016/j.apgeochem.2011.03.012.

[61] P. Ravenscroft, J. M. McArthur, M. S. Rahman, Hydrolog. Proc. 2018, 32, 3615, DOI: 10.1002/hyp. 13267.

[62] a) E. Stalder, A. Blanc, M. Haldimann, V. Dudler, Chemosphere 2012 86, 672, DOI: 10.1016/j.chemosphere.2011.11.022; b) H. R. Pfeifer, A. Häussermann, J. C. Lavanchy, W. Halter, J. Geochem. Explor. 2007, 93, 121, DOI: 10.1016/j.gexplo.2007.01.001.

[63] A. Olschewski, in 'Schweizer Gemeinde', 2019, Vol. 7/8, p. 3.

[64] M. Haldimann, Mitteil. Lebensmittelunter. Hygiene 2005, 96, 89.

[65] P. Borer, S. J. Hug, R. Sonderegger, Aqua \& Gas 2015, 4, 14.

[66] C. Biner, M. Kalbermatten, Walliser Bote 03.10.2017, https://www.1815.ch/ news/wallis/aktuell/graechen-leistet-pionierarbeit-20171003-0/.

[67] W. Koder, Walliser Bote 27.02.2019, https://www.1815.ch/news/wallis/aktuell/zu-viel-arsen-im-trinkwasser-62881/.

[68] E. Pfammatter, A. Woeffray, Walliser Bote 14.08.2019, https://www.1815.ch/ news/wallis/aktuell/walliser-wasser-von-hoher-qualitaet-101772/.

[69] S. Ayoob, A. K. Gupta, Crit. Rev. Environ. Sci. Technol. 2006, 36, 433, DOI: 10.1080/10643380600678112.

[70] D. L. Ozsvath, Rev. Environ. Sci. Biotechnol. 2009, 8, 59, DOI: 10.1007/ s11157-008-9136-9.

[71] a) R. J. Carton, Fluoride 2006, 39, 163; b) V. Kimambo, P. Bhattacharya, F. Mtalo, J. Mtamba, A. Ahmad, Groundwater for Sust. Develop. 2019, 9, DOI: 10.1016/j.gsd.2019.100223.

[72] M. G. García, L. Borgnino, in 'Fluorine: Chemistry, Analysis, Function and Effects', Ed. V. R. Preedy, 2015, p. 3.

[73] M. Amini, K. Mueller, K. C. Abbaspour, T. Rosenberg, M. Afyuni, K. N. Møller, M. Sarr, C. A. Johnson, Environ. Sci. Technol. 2008, 42, 3662, DOI: 10.1021/es071958y.

[74] M. Berg, J. E. Podgorski, in 'Proceedings: Arsenic in the Environment', CRC Press/Balkema, 2018, p. 5, DOI: 10.1201/9781351046633-2.

[75] a) M. Mohapatra, S. Anand, B. K. Mishra, D. E. Giles, P. Singh, J. Environ. Manag. 2009, 91, 67, DOI: 10.1016/j.jenvman.2009.08.015; b) A. Bhatnagar, E. Kumar, M. Sillanpää, Chem. Eng. J. 2011, 171, 811, DOI: 10.1016/j. cej.2011.05.028; c) Meenakshi, R. C. Maheshwari, J. Hazard. Mater. 2006 137, 456, DOI: 10.1016/j.jhazmat.2006.02.024.

[76] W. G. Nawlakhe, K. R. Bulusu, Indian J. Environ. Health 1978, 20, 156

[77] a) C. Y. Hu, S. L. Lo, W. H. Kuan, Water Res. 2003, 37, 4513, DOI: 10.1016/ S0043-1354(03)00378-6; b) C. Y. Hu, S. L. Lo, W. H. Kuan, Y. D. Lee, Water Res. 2005, 39, 895, DOI: 10.1016/j.watres.2004.11.034.
[78] P. Miretzky, A. F. Cirelli, J. Fluorine Chem. 2011, 132, 231, DOI: 10.1016/j. jfluchem.2011.02.001

[79] M. Srimurali, A. Pragathi, J. Karthikeyan, Environ. Poll. 1998, 99, 285, DOI: 10.1016/S0269-7491(97)00129-2.

[80] a) V. Sternitzke, M. Janousch, M. B. Heeb, J. G. Hering, C. A. Johnson, J. Crys. Growth 2014, 396, 71, DOI: 10.1016/j.jcrysgro.2014.03.036; b) V. Sternitzke, R. Kaegi, J. N. Audinot, E. Lewin, J. G. Hering, C. A. Johnson, Environ. Sci. Technol. 2012, 46, 802, DOI: 10.1021/es202750t.

[81] L. Osterwalder, C. A. Johnson, H. Yang, R. B. Johnston, Sci. Tot. Environ. 2014, 488-489, 532, DOI: 10.1016/j.scitotenv.2013.10.072.

[82] J. Inauen, R. Tobias, H. J. Mosler, Brit. J. Health Psychol. 2014, 19, 701, DOI: $10.1111 /$ bjhp. 12068 .

[83] J. Inauen, R. Tobias, H. J. Mosler, BMC Public Health 2013, 13, DOI 10.1186/1471-2458-13-417.

[84] R. Johnston, S. J. Hug, J. Inauen, N. I. Khan, H. J. Mosler, H. Yang, Sci. Tot. Environ. 2014, 488-489, 477, DOI: 10.1016/j.scitotenv.2013.11.143.

[85] H. J. Mosler, O. R. Blöchliger, J. Inauen, J. Environ. Manag. 2010, 91, 1316 , DOI: $10.1016 /$ j.jenvman.2010.02.012.

[86] I. L. Sonego, A. C. Huber, H. J. Mosler, Environ. Sci. Technol. 2013, 47, 12661, DOI: $10.1021 / \mathrm{es} 402787$ s.

[87] A. C. Huber, H. J. Mosler, J. Public Health (Germany) 2013, 21, 183, DOI: 10.1007/s10389-012-0537-4.

[88] a) A. C. Huber, S. Bhend, H. J. Mosler, J. Public Health (Germany) 2012, 20, 269, DOI: 10.1007/s10389-011-0445-z; b) A. Bretzler, C. A. Johnson, Appl. Geochem. 2015, 63, 642, DOI: 10.1016/j.apgeochem.2015.08.016.

[89] B. Mueller, S. J. Hug, Chemosphere 2018, 210, 347, DOI: 10.1016/j.chemosphere.2018.07.024.

[90] A. Bretzler, J. Nikiema, F. Lalanne, L. Hoffmann, J. Biswakarma, L. Siebenaller, D. Demange, M. Schirmer, S. J. Hug, Sci. Tot. Environ. 2020, DOI: $10.1016 /$ j.scitotenv.2020.139466.

\section{License and Terms}

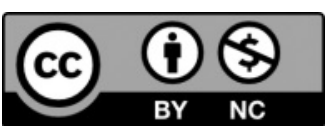

This is an Open Access article under the terms of the Creative Commons Attribution License CC BY_NC 4.0. The material may not be used for commercial purposes.

The license is subject to the CHIMIA terms and conditions: (http:// chimia.ch/component/sppagebuilder/?view=page \&id=12).

The definitive version of this article is the electronic one that can be found at doi:10.2533/chimia.2020.524 